\title{
Status of Leyte Gulf Fisheries CYs 2001-2011
}

\author{
Miriam C. Francisco ${ }^{1}$, Nancy A. Dayap ${ }^{1}$, Lea A. Tumabiene ${ }^{1, \star}$, Ruben A. Francisco, Sr., Mizpah Jay Candole ${ }^{1}$, Jaye \\ Hanne De Veyra ${ }^{1}$, Elmer Bautista ${ }^{1}$ \\ ${ }^{1}$ Bureau of Fisheries and Aquatic Resources Regional Office No. 08 Maharlika Highway, \\ Brgy. Diit, Tacloban City
}

\section{A B S T R A C T}

Leyte Gulf is among the major fishing grounds in the Philippines with a shelf area of $13,147 \mathrm{~km}^{2}$ covering the islands of Samar and Leyte. For this reason, it was chosen as the study area in Eastern Visayas under the National Stock Assessment Program (NSAP) which aims to assess the status of fisheries resources. This paper presents the fishery stock assessment results from CY 2001-2011.

The annual fish catch from 2001-2011 showed a declining trend. The lowest was in 2008 with 12, 483.52 MT while the highest was in 2003 with 26,367.32 MT. The municipal fisheries had a high catch contribution except in 2001 where commercial catch was higher by $30 \%$.

Thirty eight (38) types of fishing gears were identified operating in Leyte Gulf. Danish seine (commercial, DSC) had the highest yield in the commercial fisheries sector while for the municipal fisheries sector it was gillnet (GN). The highest catch of DSC was observed in 2004 (4,243.30 MT) and the lowest in 2010 (1,203.05 MT). The highest catch per unit of effort (CPUE) for DSC was in 2004 (288.66 kg/boat landings) and the lowest was in 2010 (167.09 kg/boat landings). For GN, the highest catch and CPUE were in 2004 (3, 010.72 MT) and 2003 (8.27 kg/boat landings) respectively; while the lowest in catch and CPUE were in 2001 (339.37 MT, $4.05 \mathrm{~kg} /$ boat landings).

The top ten (10) species caught belong to the families Leiognathidae, Carangidae, Nemipteridae, Scombridae, Gerreidae, Engraulidae, Mullidae, Synodontidae, Clupeidae, and Portunidae. The selected five (5) major stocks, which are Rastrelliger kanagurta, Leiognathus bindus, Gazza minuta, Selar crumenophthalmus, and Nemipterus hexodon were mostly abundant in the second half of the year. The percentage of catch at which they were caught before their length at maturity were as follows: 60\% for R. kanagurta, $85 \%$ for L. bindus, 13\% for G. minuta, $45 \%$ for S. crumenophthalmus, and $51 \%$ for N. hexodon.

${ }^{\star}$ E-mail Address: tumabienelea@gmail.com

Received: 25 April 2017

Accepted: 1 September2017
Keywords: Stock assessment, Leyte Gulf fisheries, population parameters, exploitation values

\section{INTRODUCTION}

$\mathrm{L}$ eyte Gulf is situated in the central eastern part of the Philippines, having a shelf area of $13,147 \mathrm{~km}^{2}$ (Silvestre 1986) covering the islands of Samar and Leyte including San Pedro Bay. It has an average depth of 38 fathoms in the central gulf and 8 fathoms in the bay. The bottom of the gulf is sandy muddy with indications of coral growth on the 15-fathom contour along the northwest coast (Warfel and Manacop 1949, cited in Edralin et al. 1992). It is characterized as multi-gear and multi-species fisheries which make it difficult to manage.

It is observable that the fisheries in the Philippines are declining, as the trends in the catch are declining. This situation is also happening in Leyte Gulf. Realizing this need to properly manage our fishery resources, a regular data collection was conducted by the Bureau of Fisheries and Aquatic Resources (BFAR) through a project called National Stock Assessment Program (NSAP), conceptualized and implemented in 1998. The output of which could be utilized in the formulation of effective fishery resource management policies for sustainable use of the resources.

This study will present the result of an 11-year assessment (2001-2011) of Leyte Gulf fisheries.

Within the context of the NSAP, this study aims to generate data on:

1. Annual (2001-2011) fish production trends, catch per unit effort (CPUE), and percentage catch contribution by sector;

2. Summary of existing fishing gears being used and percentage catch contribution;

3. The dominant families and top 10 species composition and their relative abundance; and

4. The population parameters for Rastrelliger kanagura, Leiognathus bindus, Gazza minuta, Selar crumenophthalmus, and Nemipterus hexodon. 


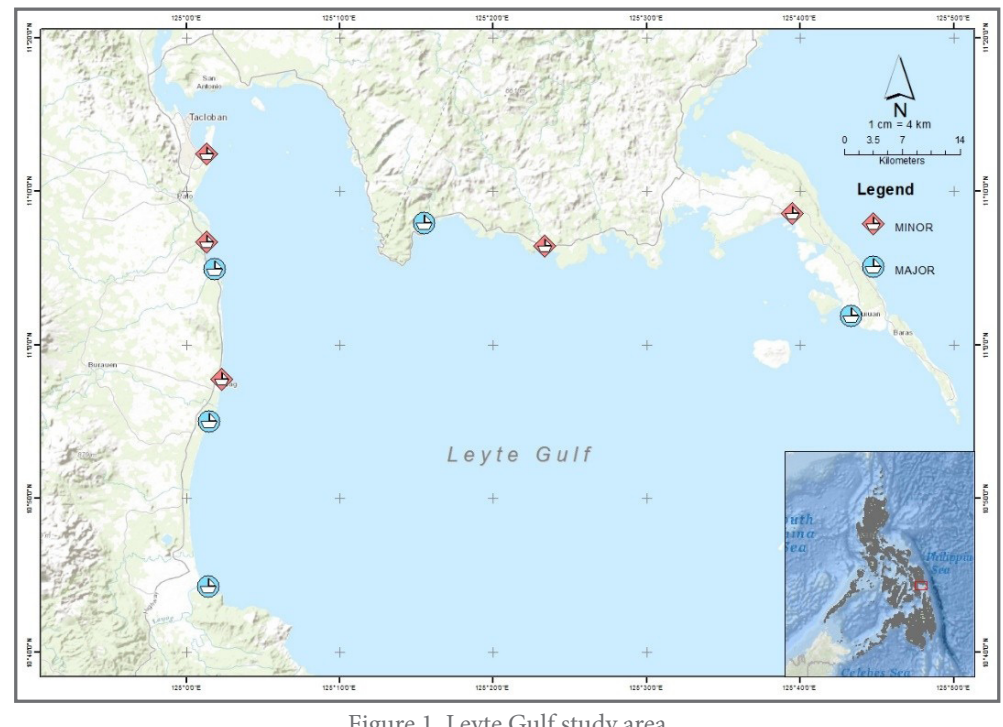

Figure 1. Leyte Gulf study area

\section{MATERIALS AND METHODS}

The data used were from primary sources, monitored landed catch of fishers. Landing sites for sampling were identified. Data processing followed the NSAP's suggested methodology. The data analyzed covered a period of 11 years, from 2001 until 2011.

\section{Sampling Sites/Landing Centers}

Ten (10) fish landing centers of municipalities surrounding Leyte Gulf were designated as sampling sites, namely: Sto. Niño, Abuyog, Leyte; Taraguna, Mc. Arthur, Leyte; Rizal and San Jose, Dulag, Leyte; and Bislig and San Roque, Tanauan, Leyte. The sampling sites in Eastern Samar are Lupok and Public Market, Guiuan and Balangiga and Lawaan (2002-2007), Salcedo. In 2008, San Jose, Tacloban was added as one of the sampling sites (Fig 1).

\section{Data Collection}

Data collection was done every after two days in each landing center with a total of 10 to 11 sampling days per month per sampling area, regardless of Saturdays, Sundays, and holidays. Two enumerators were assigned to cover alternately both minor and major landing sites. All boat landings were monitored during sampling days and the following catch and effort information were gathered:

- Name of landing center and fishing ground;

- Name of vessel/fisherman/fishing operator;

- Type of fishing gear used and corresponding effort;

- Total catch (weight) of the boat by gear type; and

- Sub-samples by weight were taken to determine the species composition in the catch by gear and the length measurements of species.

\section{Data encoding and processing}

All these information were recorded in NSAP forms. The gathered data were encoded in our NSAP Database using Microsoft Access Software.

\section{Data Analysis}

Population parameters were computed using the Electronic Length Frequency Analysis (ELEFAN) routines of the software on Fisheries Stock Assessment Tool (FiSAT II). The software computes for the fish population parameters using generally the von Bertalanffy growth function: $\mathrm{Lt}=\operatorname{Linf}\left(1-\mathrm{e}^{-\mathrm{K}(\mathrm{t}-\mathrm{to})}\right)$; where Lt is the length at age $t$; (Linf) length infinity is length that the fish of a population would reach if they were to grow indefinitely (also known as asymptotic length); $\mathrm{k}$ is the parameter of the von Bertalanffy growth function (also known as growth coefficient), expressing the rate (1/ year) at which the asymptotic length is approached; $\mathrm{e}$ is the base of Naperian logarithm, to is the hypothetical age the fish would attain at length zero.

Other population parameters with the following formula were also computed through:

Total Mortality: $\mathrm{Z}=\mathrm{M}+\mathrm{F}$. Where $\mathrm{M}$ is the instantaneous natural mortality coefficient or death caused by predation, old age, pollution, disease, etc.; and $\mathrm{F}$ is the instantaneous fishing mortality coefficient or death caused by fishing.

$\mathrm{M}$ is estimated from Pauly's empirical formula:

$$
\log \mathrm{M}=0.654 \log \mathrm{K} 0.28 \log \mathrm{L}_{\infty}+0.463 \log \mathrm{T}
$$

Where $\mathrm{L}_{\infty}$ and $\mathrm{k}$ are the von Bertalanffy growth parameters and $\mathrm{T}$ is the average temperature of the fishing ground.

These mortality components are also expressed in the form of an index to determine the rate of exploitation, 
$\mathrm{E}=\mathrm{F} / \mathrm{Z}$, Where $\mathrm{E}$ is the exploitation rate, and $\mathrm{F}$ and $\mathrm{Z}$ are fishing and total mortality coefficient

\section{RESULTSAND DISCUSSION}

\section{Monitored Annual Fish Catch}

The annual fish catch from CY 2001-2011 presented in (Figure 2) showed the highest yield of about $26,367.32 \mathrm{MT}$ in 2003 and the lowest at $12,483.52 \mathrm{MT}$ in 2008.

Fish catch from Leyte Gulf formed a plateau in 2004-2007 at 20,000 MT, then a fluctuating trend occurred from 2009 until 2011.

The landed catch data of both commercial and municipal fisheries is presented in Figure 3. could be due to the rigorous implementation of the RA No. 8550 of the Philippine Fisheries Code of 1998 which prohibits commercial fishing vessels or fishing using active gears in the municipal waters.

\section{Catch Contribution by gear, CPUE of commercial and municipal gears}

Thirty-eight (38) types of fishing gears were identified in this report and out of this number, eighteen (18) were considered active while twenty (20) were passive gears (Table 2). In an unpublished report of Francisco et al (2002), twenty-one (21) different types of fishing gears were reported operating in the Gulf in 1998: 9 active gears and 12 passive gears. This shows an increase of 17 types of gears. The number of active gears increased by three (3)

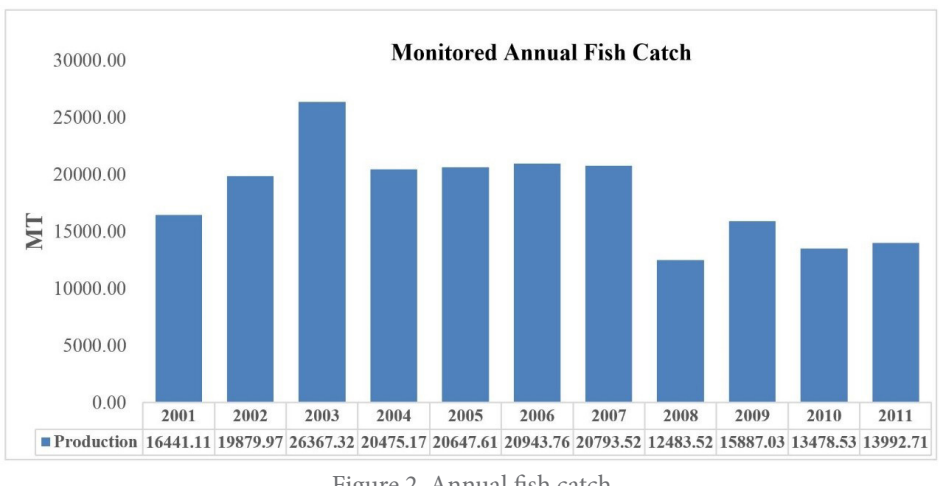

Figure 2. Annual fish catch

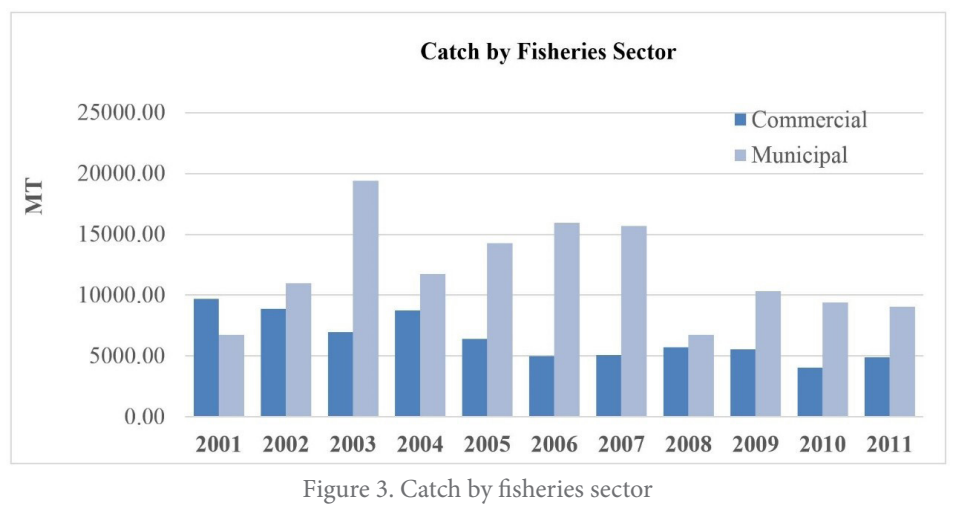

The annual fish catch of municipal fisheries sector ranged from 6, 742.93-19,405.20 MT; the lowest was recorded in 2001 and the highest in 2003. For the commercial fisheries sector, the catch ranged from, 4,070.53-9, 698.18 MT; the lowest recorded was in 2010 and the highest in 2001. Municipal fishery sector had a higher catch contribution compared to the commercial except in 2001 where it was higher by 30 percent.

Data from Philippine Fish Profile showed that from 1998-2000 the commercial catch was higher by $42.4 \%$ compared to the municipal catch. And in 2001, it was still higher by $27.22 \%$. However, in the succeeding years from 2002 until 2011, commercial fishers were replaced by municipal fishers in terms of fish catch volume. This types and the passive gears by eight (8) in a span of 9 years as three passive gears were modified (Gillnet, Liftnet, and Troll line).

DSC had the highest catch percentage of about $22.4 \%$ among active gears from 2001-2011 (Table 2). This was followed by Trawl (commercial, TC) at $17.8 \%$. The least among active gears are Modified troll line $(0.03 \%)$ and Round Haul Seine (0.003\%).

$\mathrm{GN}$, on the other hand, was highest among passive gears having a $35.67 \%$ share of the aggregate catch followed by HL with $12.13 \%$. The least were modifications of hook and line (i.e., Hook and line with 3 hooks with $0.01 \%$ and Hook and line with float with $0.003 \%$ ). 
Table 2. Summary of active and passive gears used in Leyte Gulf from 2001-2011

\begin{tabular}{|c|c|c|c|c|c|c|c|}
\hline $\begin{array}{l}\text { Gear } \\
\text { Type }\end{array}$ & & Gear Name & $\%$ & $\begin{array}{l}\text { Gear } \\
\text { Type }\end{array}$ & & Gear Name & $\%$ \\
\hline Active & 1 & Danish seine(commercial) & 20.94 & Passive & 1 & Gill net & 35.67 \\
\hline & 2 & Trawl (commercial) & 16.61 & & 2 & Hook and line & 12.13 \\
\hline & 3 & Bag net (municipal) & 15.18 & & 3 & Drift gill net & 8.38 \\
\hline & 4 & Bag net (commercial) & 13.78 & & 4 & Crab net & 8.32 \\
\hline & 5 & Ring net & 6.57 & & 5 & Modified gillnet & 6.94 \\
\hline & 6 & Danish seine & 6.56 & & 6 & Multiple hook and line & 5.28 \\
\hline & 7 & Spear gun w/ light & 6.21 & & 7 & Multiple hook and line (Pelagic) & 5.07 \\
\hline & 8 & Trawl (municipal) & 4.01 & & 8 & Hook \& line(2 hooks) & 4.13 \\
\hline & 9 & Modified liftnet & 3.51 & & 9 & Hook \& line w/ light & 3.83 \\
\hline & 10 & Troll line & 2.85 & & 10 & Fish pot & 3.38 \\
\hline & 11 & Spear gun with compressor & 1.16 & & 11 & Fish corral & 2.87 \\
\hline & 12 & Dragnet & 0.86 & & 12 & Gill net with light & 1.90 \\
\hline & 13 & Spear gun & 0.71 & & 13 & Fish trap & 1.14 \\
\hline & 14 & Push net & 0.68 & & 14 & Set gill net & 0.48 \\
\hline & 15 & Jigger & 0.20 & & 15 & Crab trap & 0.22 \\
\hline & 16 & Beach seine & 0.13 & & 16 & Squid pot & 0.11 \\
\hline & 17 & Modified troll line & 0.03 & & 17 & Multiple hook and line with light & 0.10 \\
\hline & 18 & Round haul seine & 0.003 & & 18 & Set long line & 0.04 \\
\hline & & & & & 19 & Hook and line(3 hooks) & 0.01 \\
\hline & & & & & 20 & Hook and line with float & 0.003 \\
\hline
\end{tabular}

Catch using dynamites were also accounted. Catch percentage share using dynamite increased from $0.03 \%$ to $0.13 \%$.

\section{Catch, CPUE of commercial and municipal gears}

The catch and CPUE in kilograms per boat landings of four (4) identified active commercial gears operating in Leyte Gulf are shown in Figures 4 and 5, respectively.

The catch of commercial gears are as follows: Danish seine (DSC) ranged from 1,203.05-4,243.30 MT; Trawl (TC), 1,046.37-3,802.98 MT; Bagnet (commercial, BNC), 623.56-3,053.34 MT; Ringnet (commercial, RNC), 0-2,722.64 MT. CPUE are as follows: DSC, 154.43$288.66 \mathrm{kgs} /$ boat/day; TC, 144.52-226.37 kgs/boat/day; BNC, 103.94-204.23 kgs/boat/day; RNC, 0-416.26 kgs/ boat/day.

Both the DSC and TC, considered the most efficient among gears, displayed relatively stable CPUE though they showed declining trends in fish catch (Figure 4 and 5). DSC recorded its highest catch in 2004 and the lowest in 2007 while TC's highest catch was in 2001 and the lowest in 2011. In 1998, commercial Trawl had the highest total catch percentage contribution of about 49.04\% (Francisco et al. 2002). They were replaced by Danish seine fishers in 2002 having a total catch percentage share of $18.3 \%$ while TC has $15 \%$. BNC and RNC showed an unstable catch trend from 2001-2011 due to the seasonality of target species, the anchovies. The highest recorded catch of BNC was in 2009; the lowest, however, was in 2005 (Figure 4). RNC was the least among the four gears in terms of catch with a $5 \%$ share in the total production. Its highest catch was in 2005 (Fig 4).
The CPUE of the top three (3) active fishing gears in Leyte Gulf, DSC, TC, and BNC, generally presents a linear decreasing trend except for RNC which showed the most unstable CPUE trend, not to mention that it also had the highest recorded CPUE in 2006 (Figure 5). Moreover, in a study conducted by Warfel and Manacop (1949), a CPUE of about $27.7 \mathrm{~kg} / \mathrm{hr}$ was recorded for Trawl. The results of this present study show that it has decreased to $18.9 \mathrm{~kg} / \mathrm{hr}$ in 2001 , that would be $8.8 \mathrm{~kg} / \mathrm{hr}$ decline after 52 years and an average drop of

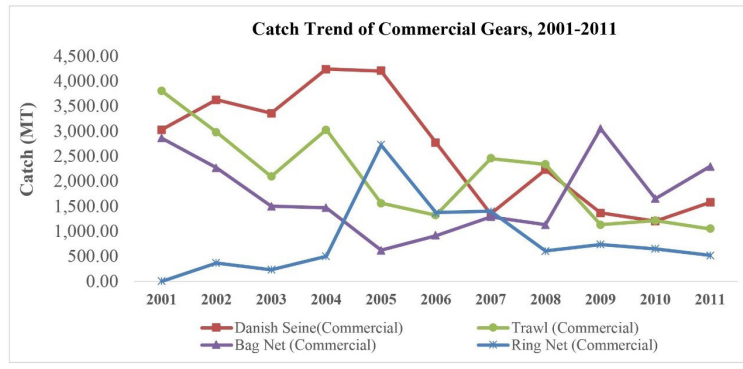

Figure 4. Catch of commercial gears, 2001-2011

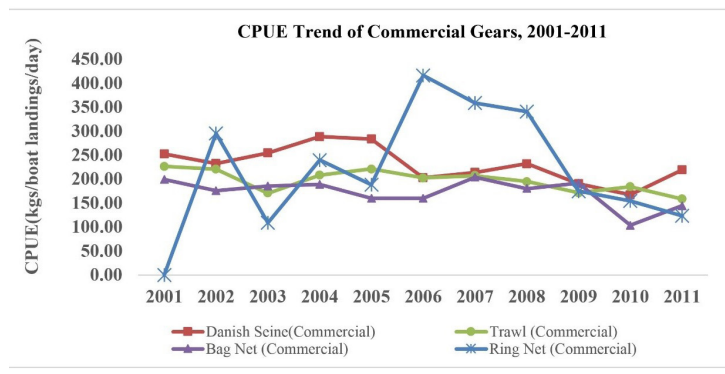

Figure 5. CPUE of commercial gears, 2001-2011 
$1.7 \mathrm{~kg} / \mathrm{hr}$ every after 10 years. Then from the results in 2001, this has further decreased to $13.21 \mathrm{~kg} / \mathrm{hr}$ in 2011 , a decline of $5.6 \mathrm{~kg} / \mathrm{hr}$ in the catch of trawl from 2001 to 2011. This shows that the rate of decline in the catch of trawl was much faster in the last 11 years, clearly showing a consequence of overfishing activities in the last 60 years.

Gillnet (GN) and Hook and line (HL), both passive gears, had the highest catch among municipal gears from 2001-2011. Their catch and CPUE are presented in Figures 6 and 7.
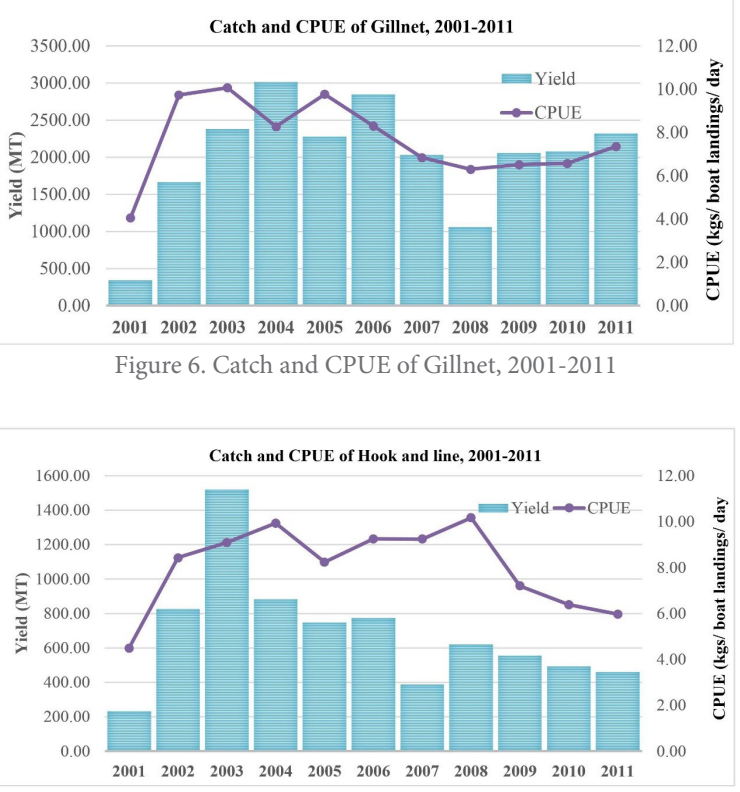

Figure 7. Catch and CPUE of Hook and line, 2001-2011

The highest observed catch of GN was about 3,010.72 MT in 2004 while the lowest was about 339.37 MT in 2001. The catch of GN showed an increasing trend from 2001 to 2004 with an average increase of $1,848.59$ MT every year. In 2008, the catch significantly dropped to 1,061.74 MT but increased the following year until 2011 (2,320.04 MT). The CPUE, on the other hand, exhibited the same kind of trend with the catch except in the years 2004 until 2006 where CPUE was low opposite to its catch. The highest recorded CPUE of GN was in 2003 at about 10.07 kilograms per boat landing per day and the lowest in 2001 at 4.05 .

Furthermore, Figure 7 shows that the highest catch of Hook and line was in 2003. CPUE of HL presented a generally fluctuating trend from 2001-2011 although with two documented peaks, in 2004 at $9.93 \mathrm{~kg} /$ boat/day and in 2008 at $10.17 \mathrm{~kg} /$ boat/day, which was also the highest recorded CPUE.

The presence of commercial fishing vessels within the municipal waters of Leyte Gulf shows a conflict in the use of resources as these gears are very efficient in catching demersal and pelagic species thereby increasing competition in the fishery with small municipal fishermen who is dependent on fishing for subsistence.

\section{Catch Composition}

The total number of families caught in Leyte Gulf from 2001 to 2011 were 142: 106 finfishes (75 percent); 5 crustaceans (3.5 percent); 7 mollusks (4.9 percent); 6 shellfish (4.2 percent); 1 sea cucumber ( 0.70 percent). The summary of the catch from 2001-2011 is presented in Figure 8 .

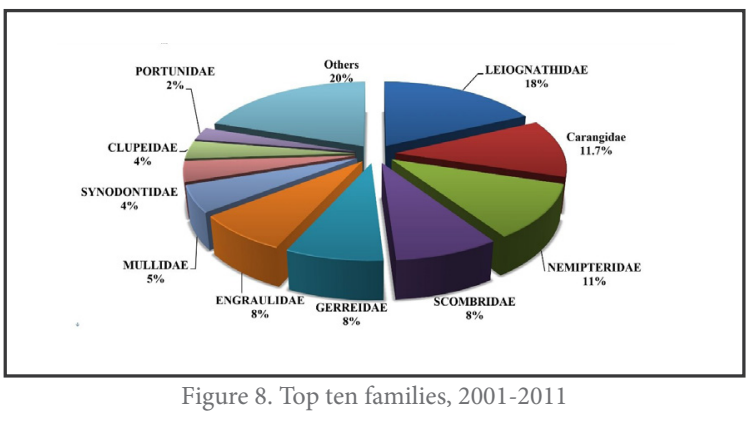

The number of species caught by municipal fishers totaled to 809 while commercial fishers have 293 from 2001-2011. This data implies that municipal waters are rich in terms of fish biodiversity. Likewise, the municipal fishers will bear a greater impact on the biodiversity of the Gulf.

Species belonging to the families Leiognathidae (Slipmouths, 18\%) were the most abundant and commonly caught in Leyte Gulf (Table 3). Leiognathus bindus $(\overline{\mathrm{x}}=10.14$ percent $)$ topped the list of the most dominant species followed by Pentaprion longimanus $(\overline{\mathrm{x}}=7.16$ percent $)$ and Encrasicholina punctifer $(\overline{\mathrm{x}}=5.88$ percent). L. bindus was observed highest in catch in the years 2001, 2002, 2005, and 2011. L. bindus is mostly caught by DSC with an average catch of 98.33 MT per year. The highest catch of DSC for this species was in 2002 with a $90.51 \%$ share. It can also be noted that E. punctifer had been on the top list of most dominant species caught for four years (2003, 2004, 2006, and 2009). E. punctifer, on the other hand, is mostly caught by Bagnet municipal and commercial. This is another indication of commercial boats fishing around the municipal waters.

The three species from the family Leiognathidae which belonged to the top 10 (Table 3) were also among the top 20 trawl-caught species in 1994-1995 in San Pedro Bay which is a part of the Leyte Gulf (Armada 1996, cited in Campos 2012). In another paper by Edralin et al. (1992) on the Leyte Gulf trawl fishery from CY 1987-1988 showed that the Carangidae (30-53\%) and Scombridae (21-30\%) dominated the whole catch. The change in the catch composition in the tropics is a common observation in a fully exploited fishing ground even when the total catch does not appear to be declining yet (Edralin et al. 1992). Moreover, a high percentage of Leiognathids (slipmouths) could also be an indicator that the demersal fish stock in the area may be heavily fished (Villoso and Aprieto 1983). 
Table 3. Relative abundance of top ten (10) species caught in Leyte Gulf for 2001, 2006, and 2011

\begin{tabular}{|c|c|c|c|c|c|}
\hline Top 10 species (2001) & $\%$ & Top 10 species (2006) & $\%$ & Top 10 species (2011) & $\%$ \\
\hline $\begin{array}{l}\text { Leiognathus bindus } \\
\text { (Leiognathidae) }\end{array}$ & 11.5 & $\begin{array}{l}\text { Encrasicholina punctifer } \\
\text { (Engraulidae) }\end{array}$ & 8.9 & $\begin{array}{l}\text { Leiognathus bindus } \\
\text { (Leiognathidae) }\end{array}$ & 17.3 \\
\hline $\begin{array}{l}\text { Pentaprion longimanus } \\
\text { (Gerreidae) }\end{array}$ & 11.2 & $\begin{array}{l}\text { Pentaprion longimanus } \\
\text { (Gerreidae) }\end{array}$ & 6.06 & $\begin{array}{l}\text { Upeneus quadrilineatus } \\
\text { (Mullidae) }\end{array}$ & 12.0 \\
\hline $\begin{array}{l}\text { Encrasicholina punctifer } \\
\text { (Engraulidae) }\end{array}$ & 4.97 & $\begin{array}{l}\text { Selaroides leptolipes } \\
\text { (Carangidae) }\end{array}$ & 5.70 & $\begin{array}{l}\text { Ratsrelliger kanagurta } \\
\text { (Scombridae) }\end{array}$ & 11.5 \\
\hline $\begin{array}{l}\text { Saurida undosquamis } \\
\text { (Synodontidae) }\end{array}$ & 4.30 & $\begin{array}{l}\text { Nemipterus hexodon } \\
\text { (Nemipteridae) }\end{array}$ & 5.63 & $\begin{array}{l}\text { Selaroides leptolipes } \\
\text { (Carangidae) }\end{array}$ & 11.0 \\
\hline $\begin{array}{l}\text { Gazza minuta } \\
\text { (Leoignathidae) }\end{array}$ & 4.13 & $\begin{array}{l}\text { Leiognathus bindus } \\
\text { (Leoignathidae) }\end{array}$ & 4.28 & $\begin{array}{l}\text { Amblygaster sirm } \\
\text { (Clupeidae) }\end{array}$ & 9.94 \\
\hline $\begin{array}{l}\text { Nemipterus hexodon } \\
\text { (Nemipteridae) }\end{array}$ & 4.0 & $\begin{array}{l}\text { Upeneus quadrilineatus } \\
\text { (Mullidae) }\end{array}$ & 3.77 & $\begin{array}{l}\text { Pentaprion longimanus } \\
\text { (Gerreidae) }\end{array}$ & 8.8 \\
\hline $\begin{array}{l}\text { Mulloidichthys vanicolensis } \\
\text { (Mullidae) }\end{array}$ & 3.88 & $\begin{array}{l}\text { Secutor indicus } \\
\text { (Leiognathidae) }\end{array}$ & 3.58 & $\begin{array}{l}\text { Nemipterus hexodon } \\
\text { (Nemipteridae) }\end{array}$ & 8.55 \\
\hline $\begin{array}{l}\text { Leiognathus splendens } \\
\text { (Leiognathidae) }\end{array}$ & 3.59 & $\begin{array}{l}\text { Portunus pelagicus } \\
\text { (Portunidae) }\end{array}$ & 3.50 & $\begin{array}{l}\text { Leiognathus splendens } \\
\text { (Leiognathidae) }\end{array}$ & 6.68 \\
\hline $\begin{array}{l}\text { Ratsrelliger kanagurta } \\
\text { (Scombridae) }\end{array}$ & 3.55 & $\begin{array}{l}\text { Gazza minuta } \\
\text { (Leoignathidae) }\end{array}$ & 3.29 & $\begin{array}{l}\text { Gazza minuta } \\
\text { (Leoignathidae) }\end{array}$ & 3.92 \\
\hline $\begin{array}{l}\text { Saurida gracilis } \\
\text { (Synodontidae) }\end{array}$ & 2.89 & $\begin{array}{l}\text { Selar crumenophthalmus } \\
\text { (Carangidae) }\end{array}$ & 3.10 & Decapterus maruadsi & 2.25 \\
\hline Others & 45.9 & Others & 52.2 & Others & 8.1 \\
\hline
\end{tabular}

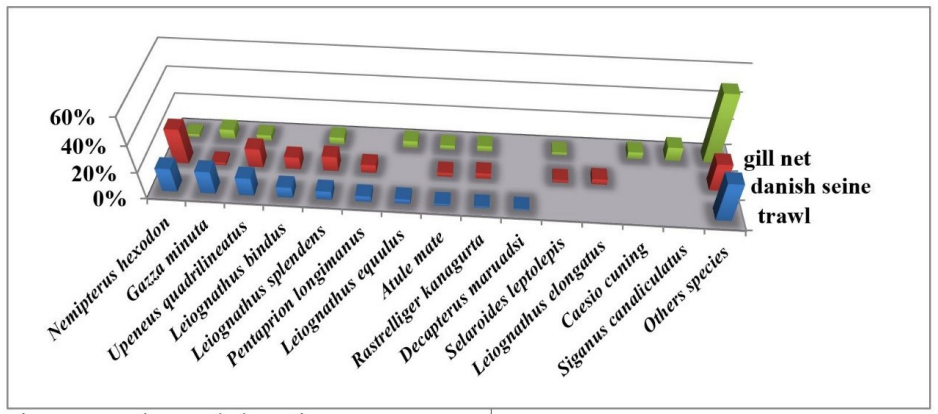

Figure 9. Species caught by major gears

In Figure 9, six out of the top ten species were caught by trawl, Danish seine, and gill net. Eight species are common between trawl and Danish seine; while nine are common to two or three of the major gears. This study found that gill nets are able to catch 603 species which is almost twice that of Danish seine (313 species) and thrice that of trawl (203 species, see Figure 9). Though gill nets are able to catcht more diversified fish species, being a stationary gear it doesn't destroy critical habitats such as seagrass beds found only in municipal waters. Further, this supports the banning of trawl and Danish seine from municipal waters since they exploit the same species beyond municipal waters but its operation destroys habitats such as coral reefs and seagrass beds located within municipal waters.

\section{Seasonality, Relative Abundance}

Armada (1996) pointed out that the estimates of population parameters of most abundant species are required in the assessment models for tropical multispecies stock. In this study five species belonging to the top 20 were subjected to this kind of analyses. The seasonality of the five is presented in Figures 10-10d.

Rastrelliger kanagurta, commonly known as Indian mackerel belongs to the top 6 most abundant species caught with a catch percentage share of 4.29 percent. It is mostly caught by DSC (66.93\%), GN (11.18\%), RN (9.27\&), and TC (5.00\%). It appeared to have two (2) peaks every year, one in the month of April and the other in the months between October until January as shown in (Figure 10).

Leiognathus bindus (Orangefin ponyfish), was observed to be abundant from May to August and November until February (Figure 10a).

Gazza minuta, locally known as Toothpony, was observed highest in production in November and January until February (Figure 10b). This is mostly caught by TC (63.70\%), DSC (13.72\%), BNC (9.65\%), and GN (7.90\%). 
Table 4. Length at maturity (Lm) of species abundant in Leyte Gulf

\begin{tabular}{|c|c|c|}
\hline Species & $\operatorname{Lm}(\mathrm{cm})$ & Source \\
\hline Rastrelliger kanagurta & 18.75 & Pathansali $(1961,1967)$ and Chee $(! 980)$ \\
\hline Leiognathus bindus & 10.0 & Froese and Pauly (2000) \\
\hline Gazza minuta & 10.0 & Jayabalan and Ramamoorthi (!980) \\
\hline Selar crumenophthalmus & 20.67 & Gonadal Examination, Otter Trawl Survey in Leyte Gulf (2014) \\
\hline Nemipterus hexodon & 19.72 & Ramos, M. H., et al (2002) \\
\hline
\end{tabular}

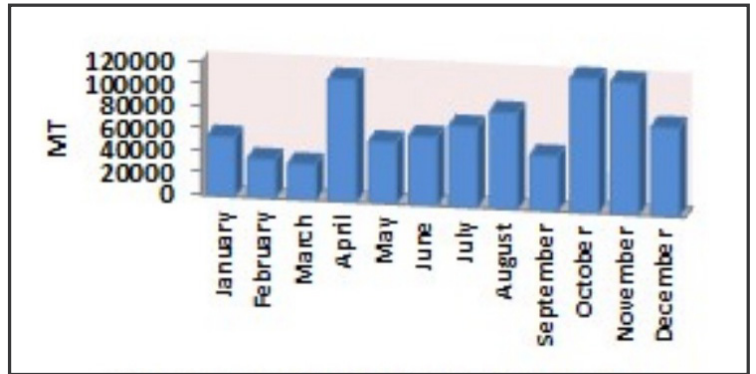

Figure 10. Seasonality of R. kanagurta, 2001 - 2011

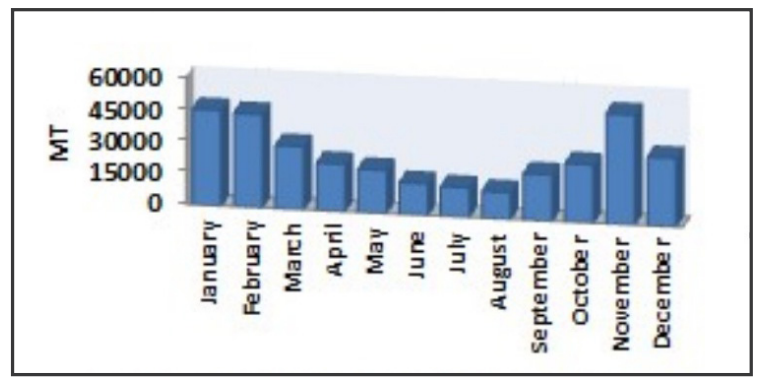

Figure 10b. Seasonality of G. minuta, 2001 - 2011

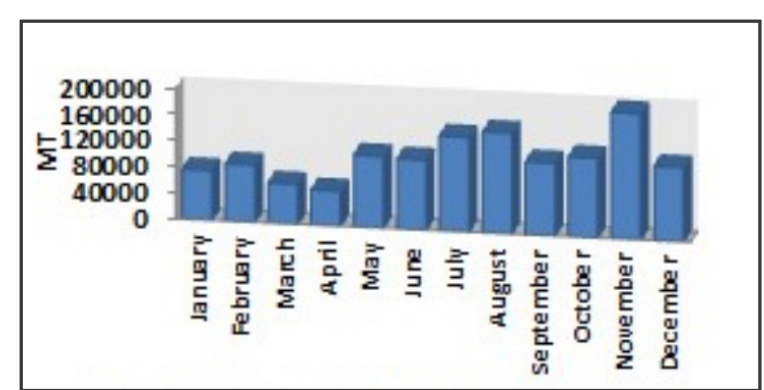

Figure 10a. Seasonality of L. bindus, 2001 - 2011

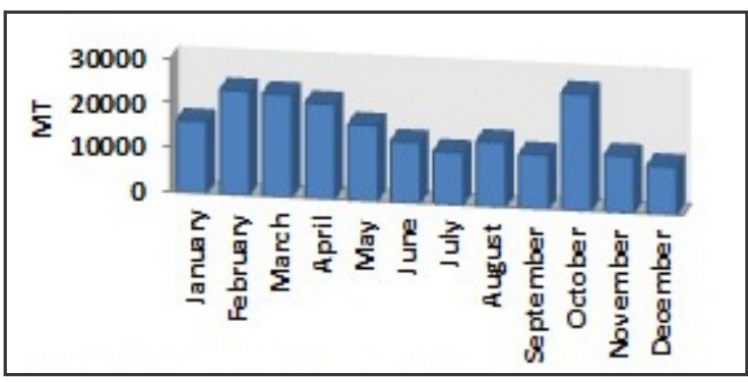

Figure 10c. Seasonality of S. crumenophthalmus, 2001 - 2011

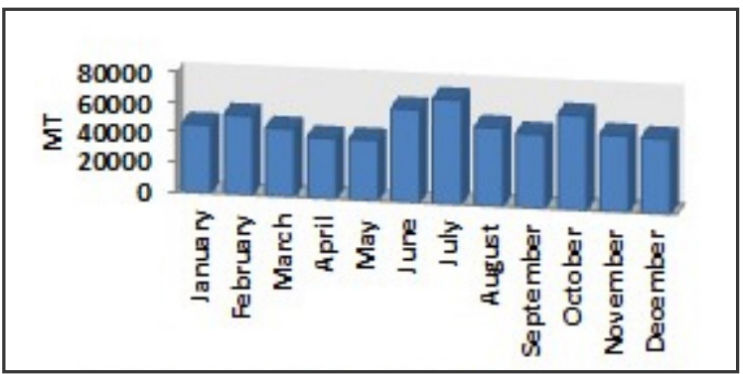

Figure 10d. Seasonality of N. hexodon, 2001 - 2011

Peak months of Selar crumenophthalmus (big eye scad) were observed to occur in October and February to March. In the study conducted by Mansor et al (1996), they identified these months as spawning periods. DSC is the top catcher of this species. It constitutes $34.67 \%$ share of the total catch followed by Multiple Hook and Line Pelagic (MHLP) with 28.81\%, GN with 23.36\%, Multiple hook and line (HL) with 5.69\%, and TC (3.95\%).

Nemipterus hexodon (Ornate threadfin bream) is relatively abundant year-round but peaks during the months of June, July, and October (Figure 10d). DSC (42.19\%), TC (37.01\%), Fish pot (11.79\%), Danish seine (3.64\%), and GN (1.96\%) are the gears that usually catch this species.
Length Frequency Distribution, Length at maturity (Lm)

The length or sizes of the five (5) dominant species (Figure 11-11d) caught in Leyte Gulf are as follows: a.) R. kanagurta $(4.25-30.25 \mathrm{~cm})$; b. ) L. bindus $(4.25-15.25 \mathrm{~cm})$; c.) G. minuta $(4.74-20.25 \mathrm{~cm})$; d.) $S$. crumenophthalmus $(9.25-30.25 \mathrm{~cm})$; e.) N. hexodon $(6.25-29.25 \mathrm{~cm})$. The values in Table 4 show the lengths at maturity of the five selected species based on supporting studies. It will be used as a standard measure of the status of the stock in support to the E-values by comparing the sizes of the catch of the top four gears that exploit the above-mentioned species which is shown in Figures 11$11 \mathrm{~d}$. 


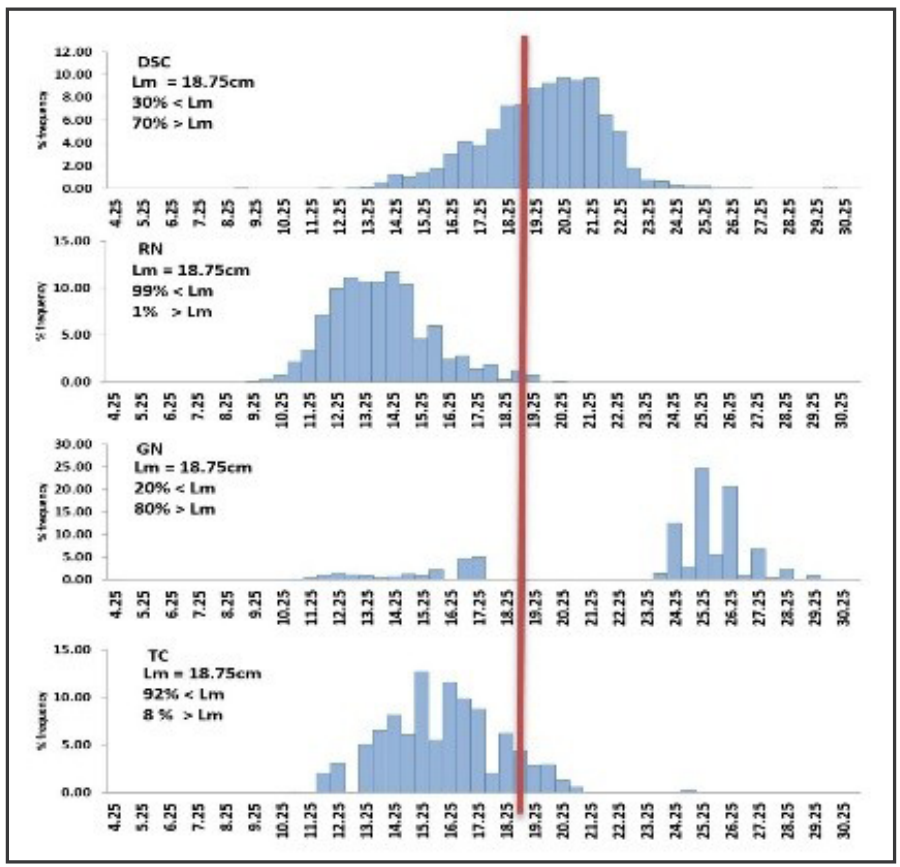

Figure 11. Length frequency distribution of $R$. kanagurta by trawl, gillnet, ring net, and Danish seine commercial from 2001-2011

R. kanagurta, considered as a high-value species, is usually caught by DSC (66.9\%), GN (11.2\%), RN (9.27\%), and TC (5.00\%). Of the four gears, RN and TC are very efficient in exploiting this species as $99 \%$ and $92 \%$, respectively, of its catch were smaller than the length at maturity $(\mathrm{Lm}=18.75 \mathrm{~cm})$. This means that only $0.84-7.85 \%$ of the stock may have been given the chance to spawn. Moreover, between GN and DSC, GN is much friendlier to the stock and is good for sustainable fishing. Only $20 \%$ was caught below the Lm (Figure 11).

$L$. bindus was the dominant stock from the aggregate production of 2001 until 2011 and was mostly caught by commercial and active gears. Fig 11a shows a high percentage of small sizes caught by commercial gears (DSC - 81 percent, TC - 75 percent, BNC - 95 percent)

G. minuta, another species that is mostly caught by the commercial gears Trawl, Danish seine, and Bagnet, have catches with size compositions that are bigger than $\mathrm{Lm}$ which is equal to $10.00 \mathrm{~cm}$. Meaning, most of the catch, if not all, are mature and may have probably reproduced since only 3-23\% were below the Lm (Figure 11b).

S. crumenophthalmus which is one commercially important species was mostly caught by the gears commercial Danish seine, gillnet, trawl commercial, and multiple hook and line. Of the five gears, GN proved again to be sustainable as it catches only $13 \%$ that was below the $\mathrm{Lm}$ which is $21 \mathrm{~cm}$. DSC and TC caught $50 \%$ and $65 \%$, respectively, that were below Lm. MHL caught $76 \%$ which was below the Lm (Figure 11c).

The size catch composition of $N$. hexodon from 2001 to 2011 by the five gears as shown in Figure 11d presents $55-93 \%$ of the stocks caught by the gears fish pots, commercial Danish seine, municipal Danish seine, and commercial Trawl were below the length of maturity which is equal to $15.30 \mathrm{~cm}$. Ninety-two (92) percent of gillnet catch was above the Lm which implies that this gear exploits $N$. hexodon that have already spawned.

These figures suggest that Leyte Gulf was experiencing growth and recruitment overfishing since the majority of the stock of the above-mentioned species were caught at relatively small sizes and some even before they were allowed to grow and reproduce. It is worth noting that these stocks are short-lived species. Hence, they can easily replenish their population in a short period of time. Therefore, this amount of fishing pressure may be considered tolerable; however, increasing it would be detrimental to the stocks or even to the state of the fishery resources.

\section{Length Infinity $\left(\mathrm{L}_{\infty}\right)$ and $k$ values}

The five (5) selected species were subjected to the FiSAT routines to get the growth parameter estimates which are shown in Table 5.

Estimates of $\mathrm{L}_{\infty}$ of $R$. kanagurta showed a fluctuating trend from 2001 to 2011 . The highest value was obtained in the year 2007 at $32.96 \mathrm{~cm}$ and the lowest at $27.03 \mathrm{~cm}$ in 2003 . The values obtained were still within the range of $\mathrm{L}_{\infty}$ 's from other literature which is 24.7-39.00 $\mathrm{cm}$. The $\mathrm{K}$ values generated by the software ranged from $0.8-1.48 \mathrm{~cm} /$ year $^{-1}$ while the k-values from other literature ranged from $0.7-1.5 \mathrm{~cm} /$ year $^{-1}$.

The $\mathrm{L}_{\infty}$ estimates of $L$. bindus varied every year. It was recorded highest at $15.75 \mathrm{~cm}$ in 2007 and lowest at $12.78 \mathrm{~cm}$ in 2005. Data from 2002 to 2003 and 2008 to 2011 were insufficient. Values for the $\mathrm{L}_{\infty}$ from other literature ranged from $8.2-13.75 \mathrm{~cm}$. K values obtained ranged from $0.84-1.80 \mathrm{~cm} /$ year $^{-1}$ while from other literature it ranged from $0.88-1.3 \mathrm{~cm} /$ year $^{-1}$. 


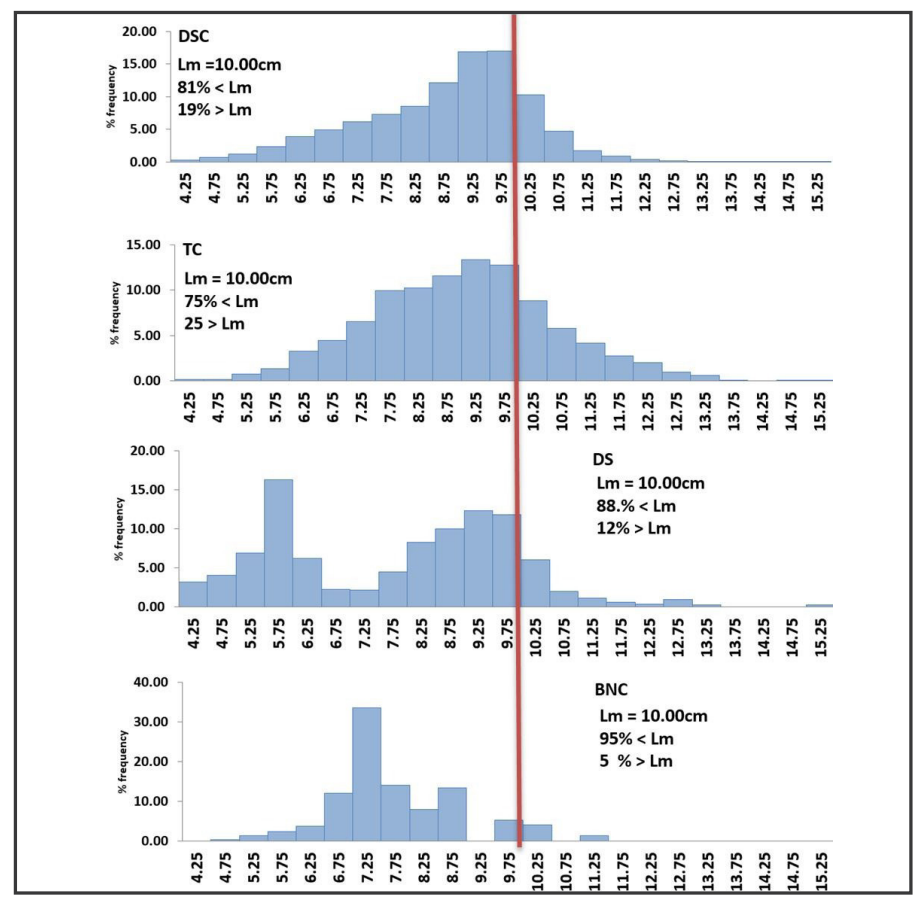

Figure 11a. Composite length frequency distribution of Leiognathus bindus caught by Danish seine commercial, trawl commercial, Danish seine (municipal), and bagnet commercial in Leyte Gulf (2001-2011)

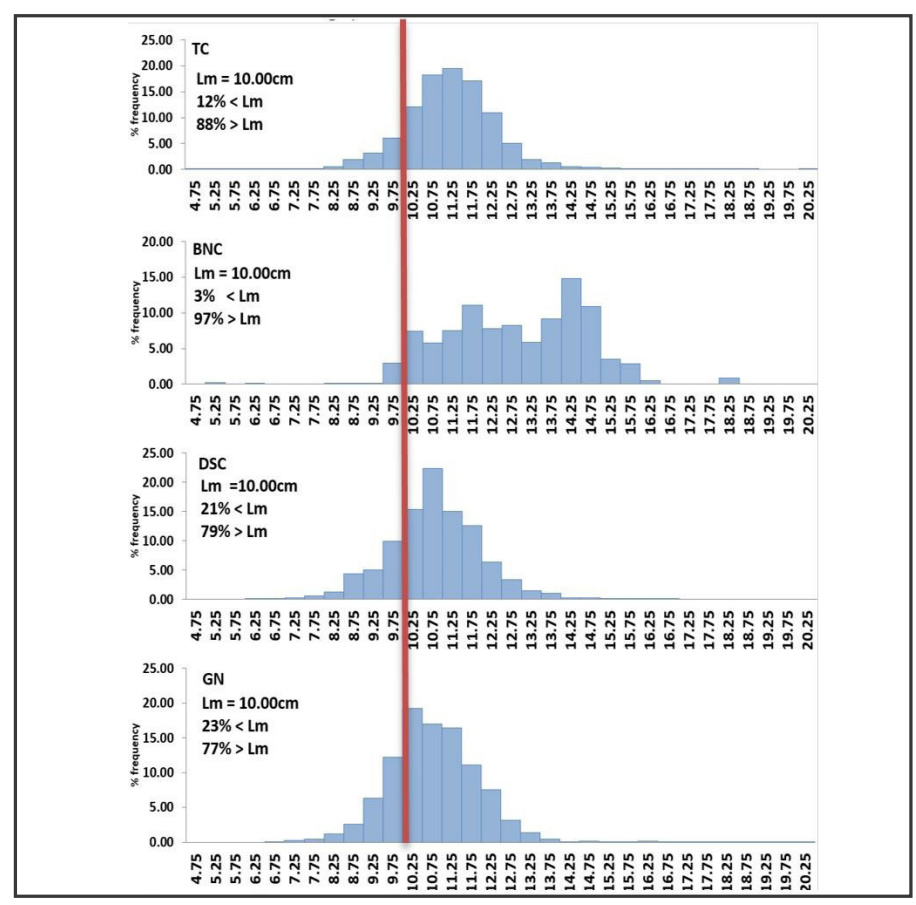

Figure 11b. Composite length frequency Distribution of Gazza minuta caught by trawl commercial, Danish seine commercial, bagnet commercial, and gillnet in Leyte Gulf (2001-2011) 


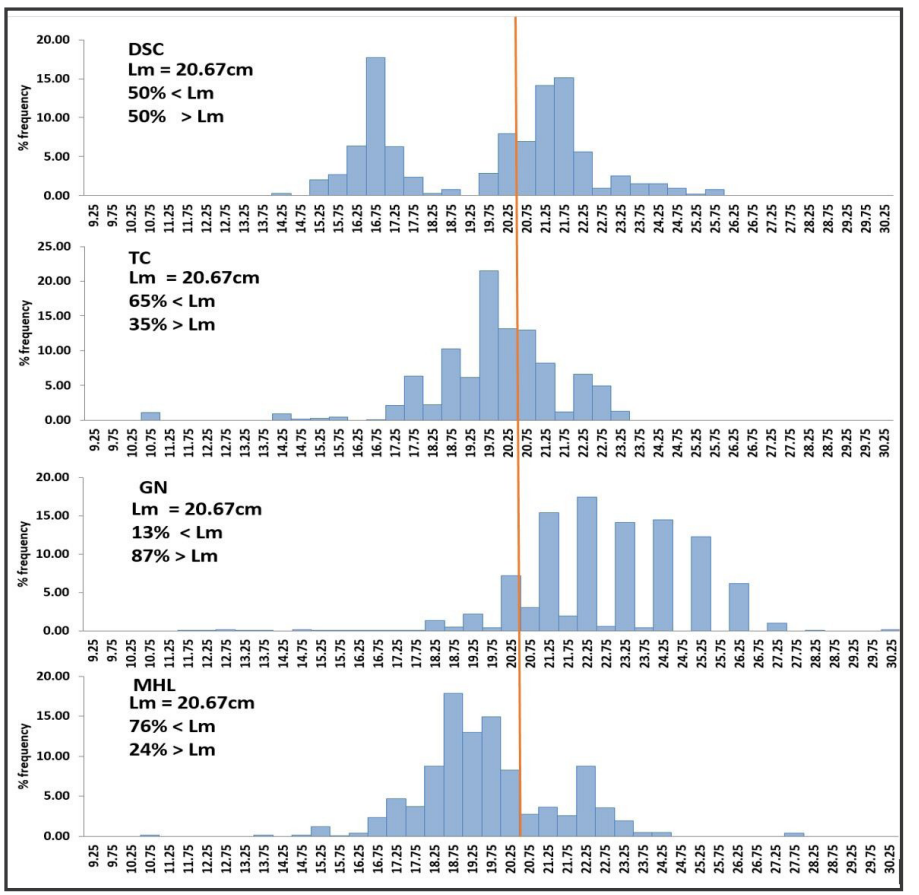

Figure 11c. Composite length frequency distribution of Selar crumenophthalmus caught

by Danish seine commercial, gillnet, trawl commercial, and multiple hook and line in Leyte Gulf (2001-2011)

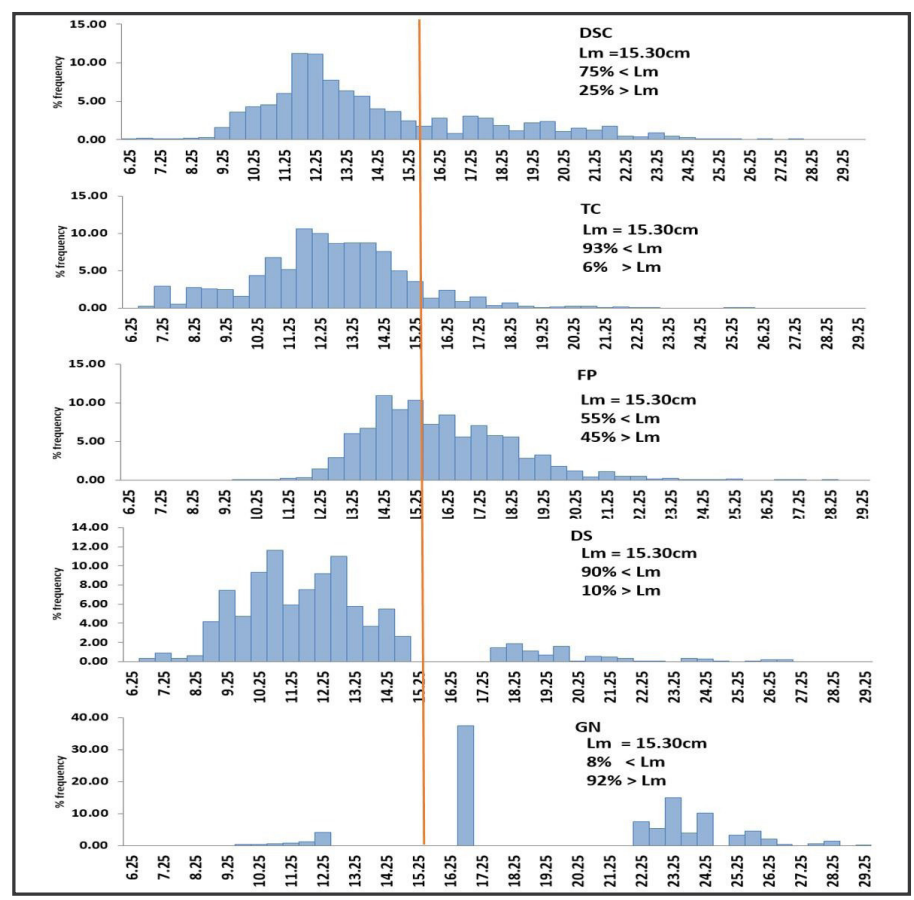

Figure 11d Composite length frequency distribution of Nemipterus hexodon caught by Danish seine commercial, trawl commercial, fish pot, Danish seine (municipal), and gillnet in Leyte Gulf (2001-2011)

The data of G. minuta that could only be analyzed by the software FiSAT was from the years 2004 until 2009. As for other years, the number of frequency (counts) of individuals were insufficient, therefore, it cannot be processed by the software. The estimates of $\mathrm{L}_{\infty}$ which ranged from $15.17-19.4 \mathrm{~cm}$ also varied each year. The highest value was obtained in 2007 and the lowest in 2008. Estimates from other literature ranged from 14.0-
$22.5 \mathrm{~cm}$. $\mathrm{K}$-values which also showed the same trend as the $\mathrm{L}_{\infty}$ ranged from $0.91-1.35 \mathrm{~cm} /$ year $^{-1}$. Although it slightly increased from $1.06 \mathrm{~cm} /$ year $^{-1}$ to $1.15 \mathrm{~cm} /$ year ${ }^{1}$ in 2004 to 2005 , it decreased to $1.1 \mathrm{~cm} /$ year $^{-1}$ the next year and then continued to fluctuate thereafter until 2009. The highest value obtained was in 2009 and the lowest in 2008 . Based on other literature, their $\mathrm{k}$ values ranged from $0.7-1.30 \mathrm{~cm} /$ year $^{-1}$. 
Table 5. Length infinity $\left(\mathrm{L}_{\infty}\right)$, and growth parameter estimates $(\mathrm{k}), 2001-2011$

\begin{tabular}{|c|c|c|c|c|c|}
\hline Species/ Year & $\mathrm{L}_{\infty}(\mathrm{cm})$ & $\mathbf{K}$ & Species/ Year & $\mathrm{L}_{\infty}(\mathrm{cm})$ & $\mathbf{K}$ \\
\hline \multicolumn{3}{|l|}{ Rastrelliger kanagurta } & \multicolumn{3}{|l|}{ Leiognathus bindus } \\
\hline 2001 & 27.89 & 1.25 & 2001 & 13.59 & 0.87 \\
\hline 2002 & 30.85 & 1.2 & 2002 & \multicolumn{2}{|c|}{ Insufficient data } \\
\hline 2003 & 27.03 & 1.2 & 2003 & \multicolumn{2}{|c|}{ Insufficient data } \\
\hline 2004 & 30.04 & 0.8 & 2004 & 14.83 & 0.84 \\
\hline 2005 & 29.03 & 1.1 & 2005 & 12.78 & 0.97 \\
\hline 2006 & 30.36 & 1.48 & 2006 & 14.2 & 1.05 \\
\hline 2007 & 32.96 & 0.8 & 2007 & 15.75 & 1.8 \\
\hline 2008 & 30.81 & 0.9 & 2008 & \multicolumn{2}{|c|}{ Insufficient data } \\
\hline 2009 & 32.39 & 0.85 & 2009 & \multicolumn{2}{|c|}{ Insufficient data } \\
\hline 2010 & 30.25 & 1.00 & 2010 & \multicolumn{2}{|c|}{ Insufficient data } \\
\hline 2011 & 29.64 & 1.09 & 2011 & \multicolumn{2}{|c|}{ Insufficient data } \\
\hline \multicolumn{3}{|l|}{ Gazza minuta } & \multicolumn{3}{|c|}{ Selar crumenophthalmus } \\
\hline 2001 & \multicolumn{2}{|c|}{ Insufficitent data } & 2001 & 26.68 & 1.06 \\
\hline 2002 & \multicolumn{2}{|c|}{ Insufficient data } & 2002 & \multicolumn{2}{|c|}{ Insufficient data } \\
\hline 2003 & \multicolumn{2}{|c|}{ Insufficient data } & 2003 & \multicolumn{2}{|c|}{ Insufficient data } \\
\hline 2004 & 16.72 & 1.06 & 2004 & 27.32 & 1.20 \\
\hline 2005 & 19.36 & 1.15 & 2005 & 30.18 & 0.82 \\
\hline 2006 & 15.96 & 1.10 & 2006 & 28.58 & 1.30 \\
\hline 2007 & 19.4 & 1.20 & 2007 & \multicolumn{2}{|c|}{ Insufficient data } \\
\hline 2008 & 15.17 & 0.91 & 2008 & 29.73 & 1.35 \\
\hline 2009 & 18.0 & 1.35 & 2009 & 26.9 & 0.95 \\
\hline 2010 & \multicolumn{2}{|c|}{ Insufficient data } & 2010 & \multicolumn{2}{|c|}{ Insufficient data } \\
\hline 2011 & \multicolumn{2}{|c|}{ Insufficient data } & 2011 & \multicolumn{2}{|c|}{ Insufficient data } \\
\hline \multicolumn{3}{|l|}{ Nemipterus hexodon } & & & \\
\hline 2001 & 32.85 & 1.0 & & & \\
\hline 2002 & 32.37 & 1.04 & & & \\
\hline 2003 & 33.62 & 0.80 & & & \\
\hline 2004 & 28.04 & 0.80 & & & \\
\hline 2005 & 32.86 & 1.0 & & & \\
\hline 2006 & \multicolumn{2}{|c|}{ Insufficient data } & & & \\
\hline 2007 & 27.30 & 0.65 & & & \\
\hline 2008 & 24.70 & 1.0 & & & \\
\hline 2009 & 25.43 & 1.0 & & & \\
\hline 2010 & 28.6 & 0.92 & & & \\
\hline
\end{tabular}

For S. crumenophthalmus, $\mathrm{L}_{\infty}$ values which ranged from 26.9-30.18 cm, varied from 2001 until 2011. It was observed highest in 2005 and lowest in 2009. From the literature, values of $\mathrm{L}_{\infty}$ range from $23.3-36.5 \mathrm{~cm}$. The $\mathrm{k}$-values obtained ranged from $0.82-1.35 \mathrm{~cm} /$ year- 1 while from other literature k-values ranged from $0.89-2.07 \mathrm{~cm} /$ year-1.

For $N$. hexodon, the $\mathrm{L}_{\infty}$ values from 2008 until 2010 were increasing, but from 2001 to 2007 the values were fluctuating. It ranged from $17.07-32.86 \mathrm{~cm}$, which was highest in 2005 and lowest in 2008. Based on other literature, $\mathrm{L}_{\infty}$ is $25.5 \mathrm{~cm}$. For the $\mathrm{k}$ values obtained, it ranged from $0.65-1.04 \mathrm{~cm} /$ year $^{-1}$ while from other literature $\mathrm{k}$ value was $0.48 \mathrm{~cm} /$ year $^{-1}$.

The species subjected to the growth analysis displayed high values of $\mathrm{k}$ and small length infinities. This suggests a high growth rate (greater than 0.5). Meaning, as they are small species of fish, they grow and mature early.

\section{Mortality and Exploitation Values}

One of the population parameters in fish stock assessments is the exploitation value (E). Researchers consider $\mathrm{E}$ values ranging from 0.4 to 0.6 as sustainable fishing. Pauly and Ingles (1984) even stated that the optimum fishing mortality of an exploited stock should be equal to the natural mortality $(\mathrm{Fopt}=\mathrm{M})$; thus, optimum exploitation rate should be equal to 0.50 . E values higher than this is already suggesting an overexploitation of the stock. The mortality of a cohort is determined by factors such as mortality due to fishing (F), mortality due to natural causes $(\mathrm{M})$, that is predation, disease, and aging. Exploitation rate (E) can be estimated given the above-mentioned factors by getting the ratio of fishing mortality over total mortality (Z) which then can be used to determine the condition of the fishing area.

The estimates of fishing mortality values of the five species presented in Table 6 were: a. R. kanagurta 
Table 6. Mortality values, 2001-2011

\begin{tabular}{|c|c|c|c|c|c|c|c|}
\hline Species/ Year & $\mathrm{Z}$ & M & $\mathbf{F}$ & Species/ Year & $\mathbf{Z}$ & $\mathbf{M}$ & $\mathbf{F}$ \\
\hline \multicolumn{4}{|l|}{ Rastrelliger kanagurta } & \multicolumn{4}{|l|}{ Leiognathus bindus } \\
\hline 2001 & 6.98 & 2.11 & 4.87 & 2001 & 4.74 & 2.04 & 2.7 \\
\hline 2002 & 11.2 & 2.0 & 9.2 & 2002 & \multicolumn{3}{|c|}{ Insufficient data } \\
\hline 2003 & 5.9 & 2.07 & 3.83 & 2003 & \multicolumn{3}{|c|}{ Insufficient data } \\
\hline 2004 & 6.3 & 1.54 & 4.76 & 2004 & 8.52 & 2.13 & 6.39 \\
\hline 2005 & 6.37 & 1.92 & 4.45 & 2005 & 4.10 & 2.37 & 1.73 \\
\hline 2006 & 4.68 & 2.3 & 2.38 & 2006 & 4.91 & 2.27 & 2.64 \\
\hline 2007 & 6.59 & 1.5 & 5.09 & 2007 & 6.91 & 3.14 & 3.77 \\
\hline 2008 & 5.61 & 1.66 & 3.96 & 2008 & \multicolumn{3}{|c|}{ Insufficient data } \\
\hline 2009 & 6.93 & 1.57 & 5.36 & 2009 & \multicolumn{3}{|c|}{ Insufficient data } \\
\hline 2010 & 6.22 & 1.78 & 4.44 & 2010 & \multicolumn{3}{|c|}{ Insufficient data } \\
\hline 2011 & 7.36 & 1.9 & 5.46 & 2011 & \multicolumn{3}{|c|}{ Insufficient data } \\
\hline \multicolumn{4}{|l|}{ Gazza minuta } & \multicolumn{4}{|c|}{ Selar crumenophthalmus } \\
\hline 2001 & \multicolumn{3}{|c|}{ Insufficient data } & 2001 & 6.01 & 1.88 & 4.13 \\
\hline 2002 & \multicolumn{3}{|c|}{ Insufficient data } & 2002 & \multicolumn{3}{|c|}{ Insufficient data } \\
\hline 2003 & \multicolumn{3}{|c|}{ Insufficient data } & 2003 & \multicolumn{3}{|c|}{ Insufficient data } \\
\hline 2004 & 6.99 & 2.18 & 4.81 & 2004 & 4.43 & 2.07 & 2.36 \\
\hline 2005 & 3.89 & 2.21 & 1.68 & 2005 & 3.5 & 1.57 & 1.93 \\
\hline 2006 & 4.71 & 2.27 & 2.44 & 2006 & 3.88 & 2.15 & 1.73 \\
\hline 2007 & 5.31 & 2.27 & 3.04 & 2007 & \multicolumn{3}{|c|}{ Insufficient data } \\
\hline 2008 & 3.38 & 2.03 & 1.35 & 2008 & 5 & 2.18 & 2.82 \\
\hline 2009 & 12.23 & 2.51 & 9.72 & 2009 & 6.79 & 1.78 & 5.01 \\
\hline 2010 & \multicolumn{3}{|c|}{ Insufficient data } & 2010 & \multicolumn{3}{|c|}{ Insufficient data } \\
\hline 2011 & \multicolumn{3}{|c|}{ Insufficient data } & 2011 & \multicolumn{3}{|c|}{ Insufficient data } \\
\hline \multicolumn{8}{|l|}{ Nemipterus hexodon } \\
\hline 2001 & 5.05 & 1.54 & 4.01 & & & & \\
\hline 2002 & 5.4 & 2.17 & 2.49 & & & & \\
\hline 2003 & 4.15 & 1.74 & 3.31 & & & & \\
\hline 2004 & 7.28 & 1.79 & 3.61 & & & & \\
\hline 2005 & 6.87 & 1.5 & 2.66 & & & & \\
\hline 2006 & \multicolumn{3}{|c|}{ Insufficient data } & & & & \\
\hline 2007 & 5.37 & 1.38 & 3.99 & & & & \\
\hline 2008 & 4.64 & 1.89 & 2.75 & & & & \\
\hline 2009 & 5.74 & 1.87 & 3.87 & & & & \\
\hline 2010 & 4.58 & 1.83 & 2.75 & & & & \\
\hline 2011 & 4.18 & 1.71 & 2.47 & & & & \\
\hline
\end{tabular}

(2.38-9.2); b. L. bindus (1.73-6.39); c. G. minuta (1.359.72); d. S. crumenophthalmus (1.73-5.01); e. N. hexodon (2.47-4.01).

The natural mortality ranges for each species were: a. R. kanagurta (1.5-2.3); b. L. bindus (2.04-3.14); c. G. minuta (2.03-2.51); d. S. crumenophthalmus (1.57$2.18)$; e. N. hexodon (1.38-2.17) as can be seen in Table 6.

The exploitation values (E) of the five major stocks presented in Figure 12 are as follows: a. R. kanagurta (0.51-0.82); b. L. bindus (0.42-0.75); c. G. minuta (0.40$0.80)$; d. S. crumenophthalmus $(0.45-0.74)$; e. N. hexodon (0.51-0.78).

These figures show that a great factor of mortality is attributed to fishing and that the exploitation rates of these stocks are very high as it ranges from 0.6-0.82. However, it also shows a fluctuating trend which means that the species can still replenish its stock although it is being overexploited. This only shows that small demersal or pelagic species can tolerate high values of exploitation due to the fact that they are early maturing. However, if destructive fishing is not suppressed and their habitat is destroyed, this might reduce fish recruitment thereby also reducing species diversity or worst, possibly eliminate a population (Dayton et al. 1995).

\section{SUMMARYANDCONCLUSION}

Leyte Gulf is an active fishing ground that is relied upon by its surrounding locals for its marine produce. After the RA 8550 has been implemented, more fishermen resorted to municipal fishing, using only gears that the law allowed to be used in municipal waters. Hence, the catch shifted from commercial to municipal fisheries that is why in some stocks, a high percentage was caught by a municipal gear that is below the length at maturity (e.g. S. crumenophthalmus - MHL at $76 \%$.

Species belonging to the families Leiognathidae (Slipmouths, 18\%) were the most abundant and 


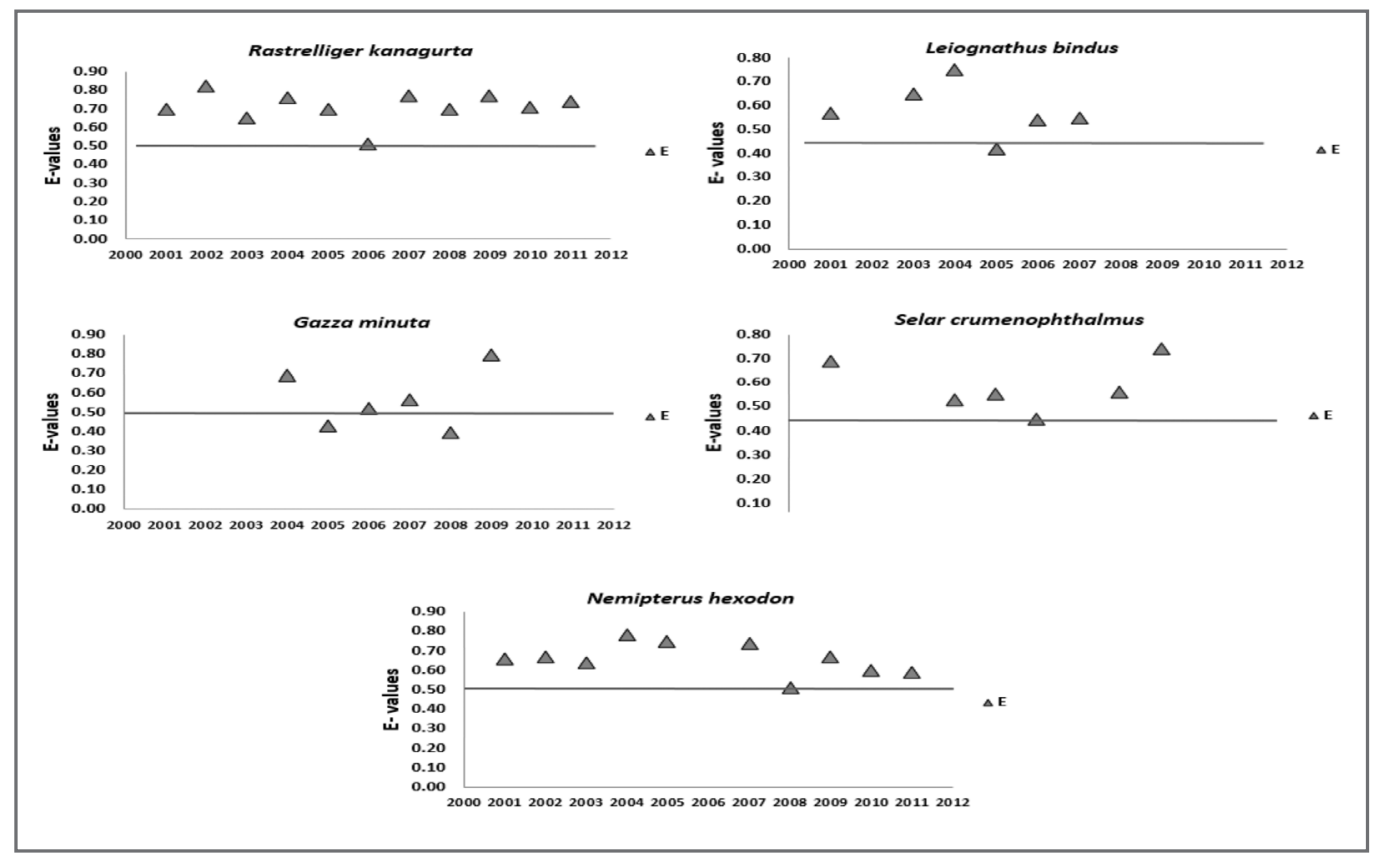

Figure 12. Exploitation values, 2001-2011

commonly caught in Leyte Gulf. This study showed that most of these species were abundant in the second half of the year, in relatively colder months while others were abundant year-round.

Armada (2004) pointed out the factors by which overfishing is occurring on a fishing ground: declining catch and catch rates, increasing effort, increasing mortalities and exploitation rates, changes or shift in species composition, leveling off of marine landings, and concentration of fishing effort within a small area. Some of these indicators were observed in Leyte Gulf. The catch has been declining in the study period of 11 years (20012011). Catch rates of Trawl also decreased by $52.31 \%$ $(14.49 \mathrm{kgs} / \mathrm{hr}$ ) in 62 years, from 1949-2011 (Warfel and Manacop 1950). The number of active gears increased by 5 types; passive gears doubled. Dynamite catch increased by $0.1 \%$. Also, majority of the stock of the five selected species observed to be experiencing recruitment overfishing were caught even before they were allowed to grow and reproduce; $20-29 \%$ of $R$. kanagurta were caught before the length at maturity; L. bindus, 75-95\%; G. minuta, 3-23\%; S. crumenophthalmus, 13-76\%; and N. hexodon, $8-93 \%$. The exploitation rates of the selected stocks were higher than the Eopt $=0.50$ : a. $R$. kanagurta (0.51-0.82); b. L. bindus (0.42-0.75); c. G. minuta (0.40$0.80)$; d. S. crumenophthalmus $(0.45-0.74)$; e. N. hexodon (0.51-0.78).

\section{A C KN OWLED GEMENT S}

We would like to extend our gratitude to the Bureau of Fisheries and Aquatic Resources Regional Office No. 8 for the financial support in making this program a success, especially to Dr. Juan D. Albaladejo for his guidance and encouragement in carrying out this paper.

For the time and extra effort put into by the enumerators in gathering the data, it is very much appreciated.

For the undying support of the NFRDI family, especially to Dr. Mudjekeewis Santos for inspiring us to write and write. Well, here's to more publications!

Finally, to the One true source of all wisdomglory and honor to you, Abba Father.

\section{REFERENCES}

Armada NB. 1996. Capture Fisheries of San Pedro Bay, Philippines. In: Resource and Ecological Assessment of San Pedro Bay Philippines, Vol. 5: The Fishery Sector Program Bureau Fisheries and Aquatic Resources (BFAR) in Cooperation with the Institute of Marine Fisheries and Oceanology (IMFO) College of Fisheries, U.P. in the Visayas, Miagao, Iloilo. 1-77.

Dayton PK et al. 1995. Viewpoint. Environmental effects of marine fishing. In: Aquatic Conservation: Marine and Freshwater Ecosystem, Vol. 5, pp. 205-232.

Edralin DT. et al. 1992. Trawl Fishing of Leyte Gulf. The Philippine Journal of Fisheries 23, A.S Legaspi (ed). 89-118.

Ingles J, Pauly D. 1984. An Atlas of the Growth, Mortality and Recruitment of Philippine Fishes. ICLARM Technical Reports 13: 137. 
Jayabalan N, Ramamoorthi K. 1986. Determination of Age and Growth in the Toothed Ponyfish, Gazza minuta (Bloch) from Porto Novo. Mahasagar-Bulletin of the Institute of Oceanography 19(3): 217-220.

Mansor, M.I. et al., 1996. Population Structure of Small Pelagic Fishes off the East Coast of Peninsular Malaysia. Fisheries Bulletin 9.

Ramos MH. 2002. The Honda Bay Fisheries: An Assessment. BFAR-NFRDI Technical Paper Series. 12(3).
Villoso EP, Aprieto VL. 1983. On the relative abundance and distribution of slipmouth (Pisces: Leiognathidae) in Lingayen Gulf. Philippines. Fish. Res. J. Phil. 8(1): 26-43.

Warfel HE, Manacop PR. 1950. Otter Trawl Explorations in Philippine Waters. Research Report 25. Fish and Wildlife Service. United States Department of the Interior. 


\section{A P P E N D I C E S}

Appendix A. Operational fishing gears, percentage catch contribution, and CPUE. CY 2001

\begin{tabular}{|c|c|c|c|c|}
\hline \multicolumn{5}{|c|}{ CY 2001} \\
\hline No. & Gear Type & $\begin{array}{c}\text { Total Catch } \\
\text { (MT) }\end{array}$ & $\%$ & $\begin{array}{c}\text { CPUE (kgs/ } \\
\text { boat land- } \\
\text { ings/day) }\end{array}$ \\
\hline \multicolumn{5}{|c|}{ ACTIVE GEAR } \\
\hline 1 & Trawl (commercial) & $3,802.98$ & 29.18 & 226.37 \\
\hline 2 & $\begin{array}{l}\text { Danish seine } \\
\text { (commercial) }\end{array}$ & $3,029.86$ & 23.25 & 252.49 \\
\hline 3 & $\begin{array}{l}\text { Bagnet (commer- } \\
\text { cial) }\end{array}$ & $2,865.34$ & 21.99 & 198.98 \\
\hline 4 & Bagnet (municipal) & $1,389.03$ & 10.66 & 137.58 \\
\hline 5 & Trawl (municipal) & 560.21 & 4.30 & 21.97 \\
\hline 6 & Modified liftnet & 369.51 & 2.84 & 64.83 \\
\hline 7 & $\begin{array}{l}\text { Spear gun with } \\
\text { light }\end{array}$ & 326.79 & 2.51 & 49.51 \\
\hline 8 & Ring net & 233.88 & 1.79 & 259.87 \\
\hline 9 & Troll line & 206.36 & 1.58 & 16.75 \\
\hline 10 & $\begin{array}{l}\text { Danish seine (mu- } \\
\text { nicipal) }\end{array}$ & 126.30 & 0.97 & 38.93 \\
\hline 11 & Spear gun & 87.32 & 0.67 & 8.32 \\
\hline 12 & Jigger & 15.93 & 0.12 & 4.30 \\
\hline 13 & Beach seine & 10.18 & 0.08 & 8.49 \\
\hline 14 & Modified troll line & 5.07 & 0.04 & 16.90 \\
\hline 15 & Round haul seine & 3.85 & 0.03 & 21.99 \\
\hline \multicolumn{2}{|l|}{ Total } & & 100.0 & \\
\hline \multicolumn{5}{|c|}{ PASSIVE GEAR } \\
\hline 16 & $\begin{array}{l}\text { Multiple hook and } \\
\text { line (pelagic) }\end{array}$ & 345.32 & 14.48 & 47.80 \\
\hline 17 & Gillnet & 339.37 & 14.23 & 4.05 \\
\hline 18 & Set gillnet & 266.91 & 11.19 & 3.78 \\
\hline 19 & Hook and line & 231.84 & 9.72 & 4.49 \\
\hline 20 & Drift gillnet & 202.33 & 8.49 & 18.83 \\
\hline 21 & Gillnet with light & 198.59 & 8.33 & 41.37 \\
\hline 22 & Crab net & 180.94 & 7.59 & 3.21 \\
\hline 23 & $\begin{array}{l}\text { Hook and light ( } 2 \\
\text { hooks) }\end{array}$ & 136.91 & 5.74 & 13.69 \\
\hline 24 & Fish corral & 132.34 & 5.55 & 21.65 \\
\hline 25 & $\begin{array}{l}\text { Multiple hook and } \\
\text { line }\end{array}$ & 112.29 & 4.71 & 5.75 \\
\hline 26 & $\begin{array}{l}\text { Hook and line with } \\
\text { light }\end{array}$ & 88.80 & 3.72 & 12.33 \\
\hline 27 & Fish trap & 63.24 & 2.65 & 7.81 \\
\hline 28 & Crab trap & 3.36 & 1.69 & 3.36 \\
\hline 29 & Fish pot & 38.90 & 1.63 & 12.0 \\
\hline 30 & $\begin{array}{l}\text { Multiple hook and } \\
\text { line with light }\end{array}$ & 4.80 & 0.20 & 15.99 \\
\hline 31 & Squid pot & 1.5 & 0.06 & 5.00 \\
\hline \multicolumn{2}{|c|}{ Total } & & 100.0 & \\
\hline \multicolumn{2}{|c|}{ Others } & & & \\
\hline 32 & Dynamite & 21.39 & & 23.12 \\
\hline
\end{tabular}

Appendix B. Operational fishing gears, percentage catch contribution, and CPUE. CY 2002

\begin{tabular}{|c|c|c|c|c|}
\hline \multicolumn{5}{|c|}{ CY 2002} \\
\hline No. & Gear Type & $\begin{array}{l}\text { Total Catch } \\
\text { (MT) }\end{array}$ & $\%$ & $\begin{array}{c}\text { CPUE (kgs/ } \\
\text { boat land- } \\
\text { ings/day) }\end{array}$ \\
\hline \multicolumn{5}{|c|}{ ACTIVE GEAR } \\
\hline 1 & $\begin{array}{l}\text { Danish seine (com- } \\
\text { mercial) }\end{array}$ & $3,631.45$ & 26.51 & 232.79 \\
\hline 2 & Trawl (commercial) & $2,982.82$ & 21.77 & 220.95 \\
\hline 3 & Bagnet (commercial) & $2,270.01$ & 16.57 & 175.97 \\
\hline 4 & Bagnet (municipal) & $2,192.97$ & 16.01 & 114.57 \\
\hline 5 & Spear gun with light & 584.19 & 4.26 & 65.23 \\
\hline 6 & $\begin{array}{l}\text { Danish seine (mu- } \\
\text { nicipal) }\end{array}$ & 513.94 & 3.75 & 42.83 \\
\hline 7 & Modified liftnet & 419.07 & 3.06 & 77.61 \\
\hline 8 & Spear gun & 363.25 & 2.65 & 13.76 \\
\hline 9 & Ring net & 362.62 & 2.65 & 295.0 \\
\hline 10 & Trawl (municipal) & 209.41 & 1.53 & 19.39 \\
\hline 11 & $\begin{array}{l}\text { Spear gun with com- } \\
\text { pressor }\end{array}$ & 111.47 & 0.81 & 9.78 \\
\hline 12 & Beach seine & 33.26 & 0.24 & 18.94 \\
\hline 13 & Jigger & 25.5 & 0.19 & 3.63 \\
\hline Tota & & & 100.0 & \\
\hline \multicolumn{5}{|c|}{ PASSIVE GEAR } \\
\hline 14 & Gillnet & 1664.76 & 27.13 & 9.74 \\
\hline 15 & Hook and line & 825.08 & 13.46 & 8.44 \\
\hline 16 & Drift gillnet & 669.96 & 10.93 & 32.89 \\
\hline 17 & Troll line & 641.88 & 10.47 & 27.48 \\
\hline 18 & Multiple hook and line & 432.05 & 7.05 & 11.66 \\
\hline 19 & $\begin{array}{l}\text { Multiple hook and line } \\
\text { (pelagic) }\end{array}$ & 421.47 & 6.88 & 30.77 \\
\hline 20 & Crab net & 404.91 & 6.61 & 3.05 \\
\hline 21 & Fish corral & 261.22 & 4.26 & 22.54 \\
\hline 22 & $\begin{array}{l}\text { Hook and line ( } 2 \\
\text { hooks) }\end{array}$ & 247.90 & 4.04 & 7.51 \\
\hline 23 & Gillnet with light & 221.95 & 3.62 & 45.14 \\
\hline 24 & $\begin{array}{l}\text { Hook and line with } \\
\text { light }\end{array}$ & 118.94 & 1.94 & 14.11 \\
\hline 25 & Fish trap & 106.25 & 1.73 & 8.07 \\
\hline 26 & Crab trap & 43.48 & 0.71 & 3.62 \\
\hline 27 & Fish pot & 36.47 & 0.60 & 5.93 \\
\hline 28 & Set gillnet & 31.31 & 0.51 & 17.83 \\
\hline 29 & Squid pot & 1.00 & 0.016 & 56.45 \\
\hline \multicolumn{2}{|c|}{ Total } & & 100.0 & \\
\hline \multicolumn{2}{|c|}{ Others } & & & \\
\hline 30 & Dynamite & 51.37 & & 34.83 \\
\hline
\end{tabular}


Appendix C. Operational fishing gears, percentage catch contribution, and CPUE. CY 2003

\begin{tabular}{|c|c|c|c|c|}
\hline \multicolumn{5}{|c|}{ CY 2003} \\
\hline No. & Gear Type & $\begin{array}{l}\text { Total Catch } \\
\quad(\mathrm{MT})\end{array}$ & $\%$ & $\begin{array}{c}\text { CPUE (kgs/ } \\
\text { boat land- } \\
\text { ings/day) }\end{array}$ \\
\hline \multicolumn{5}{|c|}{ ACTIVE GEAR } \\
\hline 1 & Bagnet (municipal) & $5,263.14$ & 32.94 & 160.95 \\
\hline 2 & $\begin{array}{l}\begin{array}{l}\text { Danish seine } \\
(\text { commercial })\end{array} \\
\end{array}$ & $3,362.44$ & 21.05 & 254.73 \\
\hline 3 & Trawl (commercial) & $2,096.56$ & 13.12 & 170.45 \\
\hline 4 & Bagnet (commercial) & $1,503.12$ & 9.41 & 185.57 \\
\hline 5 & Spear gun with light & 964.80 & 6.03 & 63.06 \\
\hline 6 & $\begin{array}{l}\text { Danish seine (mu- } \\
\text { nicipal) }\end{array}$ & 770.10 & 4.82 & 48.43 \\
\hline 7 & Troll line & 765.78 & 4.79 & 19.19 \\
\hline 8 & Modified liftnet & 232.53 & 1.46 & 64.59 \\
\hline 9 & $\begin{array}{l}\text { Spear gun with } \\
\text { compressor }\end{array}$ & 232.30 & 1.45 & 10.19 \\
\hline 10 & Ring net ( municipal) & 228.66 & 1.43 & 108.89 \\
\hline 11 & Trawl (municipal) & 227.85 & 1.43 & 15.50 \\
\hline 12 & Spear gun & 153.04 & 0.96 & 7.61 \\
\hline 13 & Jigger & 119.58 & 0.75 & 9.97 \\
\hline 14 & Modified troll line & 28.90 & 0.18 & 32.11 \\
\hline 15 & Beach seine & 26.93 & 0.17 & 8.98 \\
\hline 16 & Push net & 0.60 & 0.003 & 1.00 \\
\hline Tota & & & 100.0 & \\
\hline \multicolumn{5}{|c|}{ PASSIVE GEAR } \\
\hline 16 & Gillnet & $2,379.52$ & 22.91 & 10.07 \\
\hline 17 & $\begin{array}{l}\text { Hook and line with } \\
\text { light }\end{array}$ & $2,017.50$ & 19.43 & 12.07 \\
\hline 18 & Hook and line & $1,520.01$ & 10.93 & 9.10 \\
\hline 19 & Drift gillnet & $1,310.02$ & 12.61 & 32.59 \\
\hline 20 & Crab net & 707.65 & 6.81 & 4.17 \\
\hline 21 & $\begin{array}{l}\text { Multiple hook and } \\
\text { line (pelagic) }\end{array}$ & 668.70 & 6.44 & 28.58 \\
\hline 22 & Gillnet with light & 436.58 & 4.20 & 51.97 \\
\hline 23 & $\begin{array}{l}\text { Multiple hook and } \\
\text { line }\end{array}$ & 348.39 & 3.35 & 5.50 \\
\hline 24 & Fish corral & 339.10 & 3.26 & 17.13 \\
\hline 25 & $\begin{array}{l}\text { Hook and line ( } 2 \\
\text { hooks) }\end{array}$ & 246.81 & 2.38 & 7.62 \\
\hline 26 & Fish pot & 185.57 & 1.79 & 10.85 \\
\hline 27 & Fish trap & 176.54 & 1.70 & 7.85 \\
\hline 28 & Crab trap & 31.47 & 0.30 & 3.28 \\
\hline 29 & Squid pot & 17.14 & 0.16 & 2.72 \\
\hline \multicolumn{2}{|c|}{ Total } & & 100.0 & \\
\hline \multicolumn{5}{|c|}{ Others } \\
\hline 30 & Dynamite & 5.97 & & 19.91 \\
\hline
\end{tabular}

Appendix D. Operational fishing gears, percentage catch contribution, and CPUE. CY 2004

\begin{tabular}{|c|c|c|c|c|}
\hline \multicolumn{5}{|c|}{ CY 2004} \\
\hline No. & Gear Type & $\begin{array}{l}\text { Total Catch } \\
\quad(\mathrm{MT})\end{array}$ & $\%$ & $\begin{array}{c}\text { CPUE } \\
\text { (kgs/boat } \\
\text { landings/ } \\
\text { day) }\end{array}$ \\
\hline \multicolumn{5}{|c|}{ ACTIVE GEAR } \\
\hline 1 & $\begin{array}{l}\text { Danish seine (com- } \\
\text { mercial) }\end{array}$ & $4,243.30$ & 30.13 & 288.66 \\
\hline 2 & Trawl ( commercial) & 3, 027.97 & 21.50 & 208.27 \\
\hline 3 & Bagnet (municipal) & $2,556.20$ & 18.15 & 167.07 \\
\hline 4 & Bagnet (commercial) & $1,472.02$ & 10.45 & 188.72 \\
\hline 5 & $\begin{array}{l}\text { Danish seine } \\
\text { (municipal) }\end{array}$ & 548.50 & 3.89 & 38.90 \\
\hline 6 & Ring net & 498.47 & 3.54 & 240.00 \\
\hline 7 & Modified liftnet & 485.40 & 3.45 & 147.09 \\
\hline 8 & Troll line & 389.03 & 2.76 & 23.58 \\
\hline 9 & Spear gun with light & 289.98 & 2.06 & 48.33 \\
\hline 10 & Trawl ( municipal) & 270.94 & 1.92 & 19.09 \\
\hline 11 & $\begin{array}{l}\text { Spear gun with } \\
\text { compressor }\end{array}$ & 223.50 & 1.59 & 12.02 \\
\hline 12 & Spear gun & 57.59 & 0.41 & 6.66 \\
\hline 13 & Jigger & 12.63 & 0.09 & 5.26 \\
\hline 14 & Beach seine & 5.40 & 0.04 & 7.80 \\
\hline 15 & Modified troll line & 3.26 & 0.02 & 10.88 \\
\hline \multicolumn{2}{|c|}{ Total } & & 100.0 & \\
\hline \multicolumn{5}{|c|}{ PASSIVE GEAR } \\
\hline 16 & Gillnet & $3,010.72$ & 45.56 & 8.27 \\
\hline 17 & Drift gillnet & $1,002.02$ & 15.16 & 28.55 \\
\hline 18 & Hook and line & 883.79 & 13.37 & 9.93 \\
\hline 19 & Crab net & 739.38 & 11.19 & 4.19 \\
\hline 20 & $\begin{array}{l}\text { Hook and line ( } 2 \\
\text { hooks) }\end{array}$ & 230.61 & 3.49 & 7.76 \\
\hline 21 & Fish pot & 221.21 & 3.35 & 10.31 \\
\hline 22 & Multiple hook and line & 182.82 & 2.77 & 4.29 \\
\hline 23 & $\begin{array}{l}\text { Multiple hook and line } \\
\text { (pelagic) }\end{array}$ & 102.26 & 1.55 & 32.82 \\
\hline 24 & Fish corral & 79.93 & 1.21 & 10.66 \\
\hline 25 & Gillnet with light & 48.80 & 0.74 & 57.41 \\
\hline 26 & $\begin{array}{l}\text { Hook and line with } \\
\text { light }\end{array}$ & 23.08 & 0.35 & 3.85 \\
\hline 27 & Squid pot & 15.26 & 0.23 & 5.09 \\
\hline 28 & $\begin{array}{l}\text { Hook and line ( } 3 \\
\text { hooks) }\end{array}$ & 8.77 & 0.13 & 19.48 \\
\hline 29 & Crab trap & 5.39 & 0.08 & 1.63 \\
\hline \multicolumn{2}{|c|}{ Total } & & 100.0 & \\
\hline \multicolumn{2}{|c|}{ Others } & & & \\
\hline 30 & Dynamite & 5.80 & & 19.93 \\
\hline
\end{tabular}


Appendix E. Operational fishing gears, percentage catch contribution, and CPUE. CY 2005

\begin{tabular}{|c|c|c|c|c|}
\hline \multicolumn{5}{|c|}{ CY 2005} \\
\hline No. & Gear Type & $\begin{array}{l}\text { Total } \\
\text { Catch } \\
\text { (MT) }\end{array}$ & $\%$ & $\begin{array}{c}\text { CPUE } \\
\text { (kgs/boat } \\
\text { landings/ } \\
\text { day) }\end{array}$ \\
\hline \multicolumn{5}{|c|}{ ACTIVE GEAR } \\
\hline 1 & $\begin{array}{l}\text { Danish seine } \\
\text { (commercial) }\end{array}$ & $4,201.24$ & 28.82 & 283.27 \\
\hline 2 & Ring net & $2,722.64$ & 18.68 & 188.05 \\
\hline 3 & Trawl (Municipal) & $1,662.61$ & 11.41 & 135.17 \\
\hline 4 & Trawl (commercial) & $1,562.36$ & 10.72 & 221.22 \\
\hline 5 & Bagnet (municipal) & $1,246.28$ & 8.55 & 122.18 \\
\hline 6 & Modified liftnet & 902.83 & 6.19 & 143.31 \\
\hline 7 & Bagnet (commercial) & 623.56 & 4.28 & 159.89 \\
\hline 8 & $\begin{array}{l}\text { Danish seine (munic- } \\
\text { ipal) }\end{array}$ & 504.64 & 3.46 & 41.03 \\
\hline 9 & $\begin{array}{l}\text { Spear gun with } \\
\text { compressor }\end{array}$ & 446.94 & 3.07 & 26.60 \\
\hline 10 & Spear gun with light & 374.97 & 2.57 & 69.44 \\
\hline 11 & Troll line & 243.38 & 1.67 & 27.98 \\
\hline 12 & Spear gun & 67.71 & 1.56 & 6.45 \\
\hline 13 & Beach seine & 13.66 & 0.09 & 6.45 \\
\hline 14 & Jigger & 3.56 & 0.02 & 3.17 \\
\hline Total & & & 100.0 & \\
\hline \multicolumn{5}{|c|}{ PASSIVE GEAR } \\
\hline 15 & Gillnet & $2,279.01$ & 37.54 & 9.76 \\
\hline 16 & Drift gillnet & $1,032.01$ & 17.00 & 26.67 \\
\hline 17 & Hook and line & 748.33 & 12.32 & 8.25 \\
\hline 18 & Crab net & 603.14 & 9.93 & 3.56 \\
\hline 19 & $\begin{array}{l}\text { Hook and line ( } 2 \\
\text { hooks) }\end{array}$ & 383.58 & 6.32 & 10.23 \\
\hline 20 & Fish pot & 365.08 & 6.01 & 10.87 \\
\hline 21 & Multiple hook and line & 236.12 & 3.89 & 4.66 \\
\hline 22 & $\begin{array}{l}\text { Multiple hook and line } \\
\text { (pelagic) }\end{array}$ & 227.18 & 3.74 & 37.86 \\
\hline 23 & Fish corral & 77.62 & 1.28 & 10.78 \\
\hline 24 & Gillnet with light & 51.13 & 0.84 & 53.82 \\
\hline 25 & Fish trap & 34.25 & 0.56 & 7.14 \\
\hline 26 & Squid pot & 18.10 & 0.29 & 4.31 \\
\hline 27 & $\begin{array}{l}\text { Hook and line with } \\
\text { light }\end{array}$ & 9.63 & 0.16 & 2.92 \\
\hline 28 & $\begin{array}{l}\text { Multiple hook and line } \\
\text { with light }\end{array}$ & 3.23 & 0.05 & 3.59 \\
\hline 29 & Crab trap & 2.82 & 0.05 & 1.04 \\
\hline \multicolumn{2}{|c|}{$\begin{array}{l}\text { Total } \\
\text { Others }\end{array}$} & & 100.0 & \\
\hline \multicolumn{5}{|c|}{ Others } \\
\hline 30 & Dynamite & - & & - \\
\hline & & & & \\
\hline & & & & \\
\hline & & & & \\
\hline
\end{tabular}

Appendix F. Operational fishing gears, percentage catch contribution, and CPUE. CY 2006

\begin{tabular}{|c|c|c|c|c|}
\hline \multicolumn{5}{|c|}{ CY 2006} \\
\hline No. & Gear Type & $\begin{array}{l}\text { Total Catch } \\
\text { (MT) }\end{array}$ & $\%$ & $\begin{array}{l}\text { CPUE (kgs/ } \\
\text { boat land- } \\
\text { ings/day) }\end{array}$ \\
\hline \multicolumn{5}{|c|}{ ACTIVE GEAR } \\
\hline 1 & $\begin{array}{l}\text { Danish Seine } \\
\text { (Commercial) }\end{array}$ & $2,774.83$ & 19.59 & 202.79 \\
\hline 2 & Trawl (Municipal) & $2,619.85$ & 18.49 & 196.14 \\
\hline 3 & Bag Net (Municipal) & $2,276.55$ & 16.07 & 268.77 \\
\hline 4 & $\begin{array}{l}\text { Ring Net (Munic- } \\
\text { ipal) }\end{array}$ & $1,373.67$ & 9.70 & 416.26 \\
\hline 5 & Trawl (Commercial) & $1,319.01$ & 9.31 & 202.44 \\
\hline 6 & $\begin{array}{l}\text { Bag Net (Commer- } \\
\text { cial) }\end{array}$ & 911.91 & 6.44 & 159.98 \\
\hline 7 & Drag net & 770.70 & 5.44 & 734.00 \\
\hline 8 & Spear Gun w/ light & 744.65 & 5.26 & 59.10 \\
\hline 9 & $\begin{array}{l}\text { Spear Gun with } \\
\text { Compressor }\end{array}$ & 357.59 & 2.52 & 23.37 \\
\hline 10 & Modified Liftnet & 295.97 & 2.09 & 140.94 \\
\hline 11 & Danish Seine & 278.16 & 1.96 & 38.81 \\
\hline 12 & Push net & 211.50 & 1.49 & 352.50 \\
\hline 13 & Troll line & 109.52 & 0.77 & 18.68 \\
\hline 14 & Spear Gun & 92.93 & 0.66 & 7.20 \\
\hline 15 & Beach Seine & 30.04 & 0.21 & 46.10 \\
\hline 16 & Jigger & 21.95 & 0.15 & 6.65 \\
\hline \multicolumn{2}{|c|}{ Total } & & 100.0 & \\
\hline \multicolumn{5}{|c|}{ PASSIVE GEAR } \\
\hline 17 & Gill Net & $2,844.57$ & 42.15 & 8.30 \\
\hline 18 & Modified Gillnet & 899.64 & 13.33 & 25.33 \\
\hline 19 & Hook \& Line & 774.31 & 11.47 & 9.25 \\
\hline 20 & Crab Net & 436.42 & 6.47 & 3.21 \\
\hline 21 & $\begin{array}{l}\text { Multiple Hook \& } \\
\text { line (Pelagic) }\end{array}$ & 375.77 & 5.57 & 40.41 \\
\hline 22 & Fish Pot & 343.88 & 5.10 & 8.43 \\
\hline 23 & $\begin{array}{l}\text { Hook \& line }(2 \\
\text { Hooks) }\end{array}$ & 331.91 & 4.92 & 8.51 \\
\hline 24 & Drift Gill Net & 276.54 & 4.10 & 27.93 \\
\hline 25 & $\begin{array}{l}\text { Multiple Hook \& } \\
\text { Line }\end{array}$ & 229.06 & 3.39 & 4.39 \\
\hline 26 & Fish Coral & 144.55 & 2.14 & 11.21 \\
\hline 27 & Fish Trap & 49.92 & 0.45 & 7.56 \\
\hline 28 & $\begin{array}{l}\text { Hook \& Line w/ } \\
\text { light }\end{array}$ & 11.83 & & 4.54 \\
\hline 29 & $\begin{array}{l}\text { Multiple Hook \& } \\
\text { line w/ light }\end{array}$ & 10.61 & 0.18 & 21.21 \\
\hline 30 & Gill Net w/ light & 7.88 & 0.16 & 52.50 \\
\hline 31 & Set Long Line & 5.40 & 0.12 & 18.00 \\
\hline 32 & Squid Pot & 3.31 & 0.08 & 2.28 \\
\hline 33 & Crab Trap & 3.07 & 0.05 & 1.14 \\
\hline \multirow{2}{*}{\multicolumn{2}{|c|}{$\begin{array}{l}\text { Total } \\
\text { Others }\end{array}$}} & & 100.0 & \\
\hline & & & & \\
\hline 34 & Dynamite & - & & \\
\hline
\end{tabular}


Appendix G. Operational fishing gears, percentage catch contribution, and CPUE. CY 2007

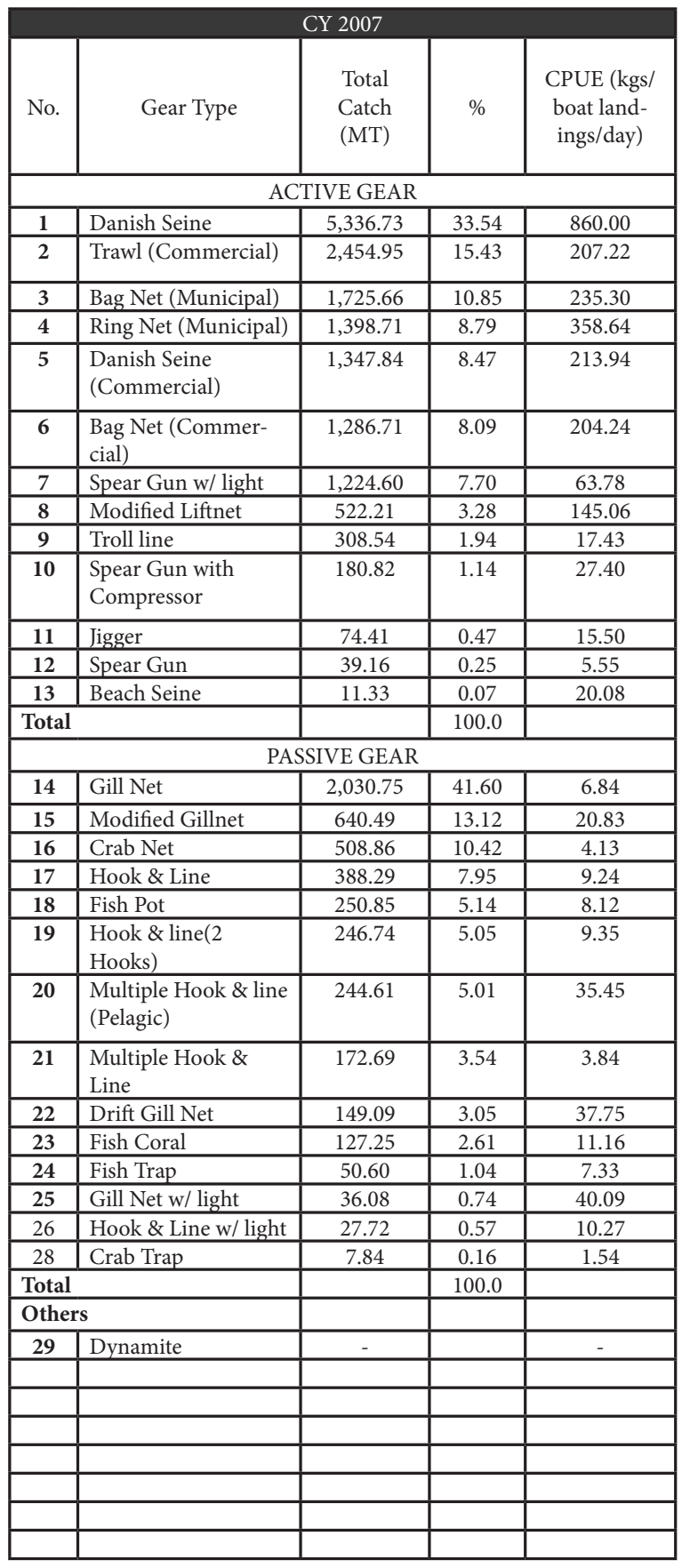

Appendix H. Operational fishing gears, percentage catch contribution, and CPUE. CY 2008

\begin{tabular}{|c|c|c|c|c|}
\hline \multicolumn{5}{|c|}{ CY 2008} \\
\hline No. & Gear Type & $\begin{array}{l}\text { Total } \\
\text { Catch } \\
\text { (MT) }\end{array}$ & $\%$ & $\begin{array}{l}\text { CPUE (kgs/ } \\
\text { boat land- } \\
\text { ings/day) }\end{array}$ \\
\hline \multicolumn{5}{|c|}{ ACTIVE GEAR } \\
\hline 1 & Trawl (Commercial) & $2,338.74$ & 26.52 & 194.89 \\
\hline 2 & $\begin{array}{l}\text { Danish Seine } \\
(\text { Commercial) }\end{array}$ & $2,228.91$ & 25.28 & 232.18 \\
\hline 3 & Bag Net (Commercial) & $1,135.72$ & 12.88 & 180.27 \\
\hline 4 & Spear Gun w/ light & 926.49 & 10.51 & 68.63 \\
\hline 5 & Ring Net & 606.21 & 6.87 & 340.79 \\
\hline 6 & Bag Net (Municipal) & 426.80 & 4.84 & 81.83 \\
\hline 7 & Drag net & 421.75 & 4.78 & 401.67 \\
\hline 8 & Troll line & 306.72 & 3.48 & 15.73 \\
\hline 9 & Modified Liftnet & 179.70 & 2.04 & 119.80 \\
\hline 10 & $\begin{array}{l}\text { Danish Seine } \\
\end{array}$ & 154.09 & 1.75 & 25.00 \\
\hline 11 & Spear Gun & 36.92 & 0.42 & 6.23 \\
\hline 12 & \begin{tabular}{|l} 
Push net \\
\end{tabular} & 27.60 & 0.31 & 92.00 \\
\hline 13 & Beach Seine & 22.93 & 0.26 & 48.35 \\
\hline 14 & Jigger & 5.36 & 0.06 & 17.85 \\
\hline Tota & & & 100.0 & \\
\hline \multicolumn{5}{|c|}{ PASSIVE GEAR } \\
\hline 15 & Gill Net & $1,061.74$ & 28.99 & 6.30 \\
\hline 16 & Hook \& Line & 619.71 & 16.92 & 10.17 \\
\hline 17 & \begin{tabular}{|l|} 
Modified Gillnet \\
\end{tabular} & 478.31 & 13.06 & 18.51 \\
\hline 18 & Crab Net & 287.32 & 7.85 & 5.54 \\
\hline 19 & Multiple Hook \& Line & 232.68 & 6.35 & 4.70 \\
\hline 20 & \begin{tabular}{|l|} 
Fish Pot \\
\end{tabular} & 212.91 & 5.81 & 7.97 \\
\hline 21 & Hook \& line (2 Hooks) & 205.19 & 5.60 & 5.90 \\
\hline 22 & \begin{tabular}{|l|} 
Drift Gill Net \\
\end{tabular} & 164.28 & 4.49 & 36.51 \\
\hline 23 & Fish Coral & 152.17 & 4.16 & 10.79 \\
\hline 24 & $\begin{array}{l}\text { Multiple Hook \& line } \\
\text { (Pelagic) }\end{array}$ & 144.34 & 3.94 & 24.06 \\
\hline 25 & \begin{tabular}{|l} 
Fish Trap \\
\end{tabular} & 41.55 & 1.13 & 6.59 \\
\hline 26 & Gill Net w/ light & 34.86 & 0.95 & 29.05 \\
\hline 27 & Hook \& Line w/ light & 17.81 & 0.49 & 6.59 \\
\hline 28 & $\begin{array}{l}\text { Multiple Hook \& line } \\
\text { w/ light }\end{array}$ & 6.34 & 0.17 & 2.21 \\
\hline 29 & $\begin{array}{l}\text { Hook and line with } \\
\text { float }\end{array}$ & 2.02 & 0.06 & 6.73 \\
\hline 30 & \begin{tabular}{|l|} 
Crab Trap \\
\end{tabular} & 0.60 & 0.02 & 1.19 \\
\hline \multicolumn{2}{|c|}{ Total } & & 100.0 & \\
\hline \multicolumn{5}{|c|}{ Others } \\
\hline 31 & Dynamite & 3.75 & & 12.50 \\
\hline & & & & \\
\hline & & & & \\
\hline & & & & \\
\hline & & & & \\
\hline
\end{tabular}


Appendix I. Operational fishing gears, percentage catch contribution, and CPUE. CY 2009

\begin{tabular}{|c|c|c|c|c|}
\hline \multicolumn{5}{|c|}{ CY 2009} \\
\hline No. & Gear Type & $\begin{array}{l}\text { Total } \\
\text { Catch } \\
\text { (MT) }\end{array}$ & $\%$ & $\begin{array}{c}\text { CPUE (kgs/ } \\
\text { boat land- } \\
\text { ings/day) }\end{array}$ \\
\hline \multicolumn{5}{|c|}{ ACTIVE GEAR } \\
\hline 1 & Bag Net (Commercial) & $3,053.34$ & 28.03 & 192.03 \\
\hline 2 & Bag Net (Municipal) & $1,945.45$ & 17.86 & 154.40 \\
\hline 3 & $\begin{array}{l}\text { Danish Seine } \\
\text { (Commercial) }\end{array}$ & $1,370.32$ & 12.58 & 190.32 \\
\hline 4 & Trawl (Commercial) & $1,132.22$ & 10.39 & 171.55 \\
\hline 5 & Spear Gun w/ light & $1,046.24$ & 9.60 & 81.10 \\
\hline 6 & Ring Net (Municipal) & 734.39 & 6.74 & 174.86 \\
\hline 7 & Modified Liftnet & 462.38 & 4.24 & 140.12 \\
\hline 8 & Push net & 419.00 & 3.85 & 698.33 \\
\hline 9 & Danish Seine & 328.41 & 3.01 & 14.03 \\
\hline 10 & Troll line & 314.21 & 2.88 & 16.89 \\
\hline 11 & $\begin{array}{l}\text { Spear Gun with } \\
\text { Compressor }\end{array}$ & 41.27 & 0.38 & 9.83 \\
\hline 12 & Spear Gun & 37.64 & 0.35 & 10.46 \\
\hline 13 & Beach Seine & 8.05 & 0.07 & 13.42 \\
\hline \multicolumn{2}{|c|}{ Total } & & 100.0 & \\
\hline \multicolumn{5}{|c|}{ PASSIVE GEAR } \\
\hline 14 & Gill Net & $2,054.90$ & 41.32 & 6.51 \\
\hline 15 & Modified Gillnet & 669.25 & 13.46 & 20.47 \\
\hline 16 & Hook \& Line & 555.66 & 11.17 & 7.21 \\
\hline 17 & Crab Net & 404.97 & 8.14 & 6.37 \\
\hline 18 & Multiple Hook \& Line & 384.39 & 7.73 & 12.09 \\
\hline 19 & Hook \& line (2 Hooks) & 181.48 & 3.65 & 5.40 \\
\hline 20 & $\begin{array}{l}\text { Multiple Hook \& line } \\
\text { (Pelagic) }\end{array}$ & 169.28 & 3.40 & 25.65 \\
\hline 21 & Fish Coral & 155.11 & 3.12 & 11.00 \\
\hline 22 & Fish Pot & 147.54 & 2.97 & 7.93 \\
\hline 23 & Drift Gill Net & 130.72 & 2.63 & 31.12 \\
\hline 24 & Fish Trap & 48.63 & 0.98 & 7.37 \\
\hline 25 & Gill Net $w /$ light & 36.58 & 0.74 & 32.51 \\
\hline 26 & $\begin{array}{l}\text { Multiple Hook \& line } \\
\text { w/ light }\end{array}$ & 19.38 & 0.39 & 21.53 \\
\hline 27 & Hook \& Line w/ light & 15.67 & 0.32 & 6.53 \\
\hline \multicolumn{2}{|c|}{ Total } & & 100.0 & \\
\hline \multicolumn{2}{|c|}{ Others } & & & \\
\hline 28 & Dynamite & 20.57 & & 22.86 \\
\hline
\end{tabular}

Appendix J. Operational fishing gears, percentage catch contribution, and CPUE. CY 2010

\begin{tabular}{|c|c|c|c|c|}
\hline \multicolumn{5}{|c|}{ CY 2010} \\
\hline No. & Gear Type & $\begin{array}{l}\text { Total Catch } \\
\text { (MT) }\end{array}$ & $\%$ & $\begin{array}{l}\text { CPUE (kgs/ } \\
\text { boat land- } \\
\text { ings/day) }\end{array}$ \\
\hline \multicolumn{5}{|c|}{$\begin{array}{r}\text { ACTIVE GEAR } \\
\end{array}$} \\
\hline 1 & Bag Net (Commercial) & $1,652.58$ & 20.41 & 103.94 \\
\hline 2 & Trawl (Commercial) & $1,214.89$ & 15.00 & 184.07 \\
\hline 3 & $\begin{array}{l}\text { Danish Seine } \\
\text { (Commercial) }\end{array}$ & $1,203.05$ & 14.86 & 167.09 \\
\hline 4 & Spear Gun w/ light & $1,182.33$ & 14.60 & 91.65 \\
\hline 5 & Bag Net (Municipal) & $1,104.35$ & 13.64 & 87.65 \\
\hline 6 & Ring Net (Municipal) & 648.60 & 8.01 & 154.43 \\
\hline 7 & Modified Liftnet & 505.27 & 6.24 & 153.11 \\
\hline 8 & Danish Seine & 251.38 & 3.10 & 10.74 \\
\hline 9 & Troll line & 217.24 & 2.68 & 11.68 \\
\hline 10 & Push net & 89.14 & 1.10 & 148.57 \\
\hline 11 & Spear Gun & 21.29 & 0.26 & 5.91 \\
\hline 12 & Beach Seine & 7.56 & 0.09 & 12.60 \\
\hline Total & & & 100.0 & \\
\hline \multicolumn{5}{|c|}{ PASSIVE GEAR } \\
\hline 13 & Gill Net & $2,076.65$ & 38.77 & 6.58 \\
\hline 14 & Modified Gillnet & 774.99 & 14.47 & 23.70 \\
\hline 15 & Multiple Hook \& Line & 655.86 & 12.25 & 20.62 \\
\hline 16 & Hook \& Line & 492.36 & 9.19 & 6.39 \\
\hline 17 & Crab Net & 407.86 & 7.62 & 6.41 \\
\hline 18 & $\begin{array}{l}\text { Multiple Hook \& line } \\
\text { (Pelagic) }\end{array}$ & 205.42 & 3.84 & 31.12 \\
\hline 19 & Hook \& line (2 Hooks) & 177.96 & 3.32 & 5.30 \\
\hline 20 & Fish Pot & 143.63 & 2.68 & 7.72 \\
\hline 21 & Fish Coral & 142.49 & 2.66 & 10.11 \\
\hline 22 & Drift Gill Net & 131.00 & 2.45 & 31.19 \\
\hline 23 & Gill Net w/ light & 59.36 & 1.11 & 52.77 \\
\hline 24 & Fish Trap & 45.06 & 0.84 & 6.83 \\
\hline 25 & $\begin{array}{l}\text { Multiple Hook \& line } \\
\text { w/ light }\end{array}$ & 17.17 & 0.32 & 19.08 \\
\hline 26 & Hook \& Line w/ light & 13.73 & 0.26 & 5.72 \\
\hline 27 & Set Long Line & 6.33 & 0.12 & 21.11 \\
\hline 28 & Squid Pot & 5.80 & 0.11 & 4.00 \\
\hline \multicolumn{2}{|c|}{ Total } & & 100.0 & \\
\hline \multicolumn{2}{|c|}{ Others } & & & \\
\hline 29 & Dynamite & 25.15 & & 27.95 \\
\hline
\end{tabular}


Appendix K. Operational fishing gears, percentage catch contribution, and CPUE. CY 2011

\begin{tabular}{|c|c|c|c|c|}
\hline \multicolumn{5}{|c|}{ CY 2011} \\
\hline No. & Gear Type & $\begin{array}{c}\text { Total Catch } \\
(\mathrm{MT})\end{array}$ & $\%$ & $\begin{array}{c}\text { CPUE (kgs/boat } \\
\text { landings/day) }\end{array}$ \\
\hline \multicolumn{5}{|c|}{ ACTIVE GEAR } \\
\hline 1 & Bag Net (Commercial) & $2,297.92$ & 26.50 & 144.52 \\
\hline 2 & Danish Seine (Commercial) & $1,577.21$ & 18.19 & 219.06 \\
\hline 3 & Trawl (Commercial) & $1,046.37$ & 12.07 & 158.54 \\
\hline 4 & Spear Gun w/ light & 931.67 & 10.74 & 72.22 \\
\hline 5 & Bag Net (Municipal) & 882.88 & 10.18 & 70.07 \\
\hline 6 & Ring Net (Municipal) & 519.18 & 5.99 & 123.62 \\
\hline 7 & Modified Liftnet & 480.68 & 5.54 & 145.66 \\
\hline 8 & Troll line & 445.41 & 5.14 & 23.95 \\
\hline 9 & Danish Seine & 265.17 & 3.06 & 11.33 \\
\hline 10 & Push net & 186.43 & 2.15 & 310.71 \\
\hline 11 & Spear Gun & 21.05 & 0.24 & 5.85 \\
\hline 12 & $\begin{array}{l}\text { Spear Gun with } \\
\text { Compressor }\end{array}$ & 14.49 & 0.17 & 3.45 \\
\hline 13 & Beach Seine & 3.70 & 0.04 & 6.17 \\
\hline Total & & & 100.0 & \\
\hline \multicolumn{5}{|c|}{ PASSIVE GEAR } \\
\hline 14 & Gill Net & $2,320.04$ & 43.83 & 7.35 \\
\hline 15 & Modified Gillnet & 831.76 & 15.71 & 25.44 \\
\hline 16 & Crab Net & 465.31 & 8.79 & 7.32 \\
\hline 17 & Hook \& Line & 460.24 & 8.70 & 5.97 \\
\hline 18 & Multiple Hook \& Line & 278.23 & 5.26 & 8.75 \\
\hline 19 & Multiple Hook \& line (Pelagic) & 234.47 & 4.43 & 35.53 \\
\hline 20 & Hook \& line(2 Hooks) & 165.63 & 3.13 & 4.93 \\
\hline 21 & Fish Coral & 163.66 & 3.09 & 11.61 \\
\hline 22 & Fish Pot & 145.10 & 2.74 & 7.80 \\
\hline 23 & Drift Gill Net & 114.42 & 2.16 & 27.24 \\
\hline 24 & Fish Trap & 47.13 & 0.89 & 7.14 \\
\hline 25 & Gill Net w/ light & 41.12 & 0.78 & 36.55 \\
\hline 26 & Hook \& Line w/ light & 22.44 & 0.42 & 9.35 \\
\hline 27 & Squid Pot & 3.63 & 0.07 & 2.50 \\
\hline \multicolumn{2}{|c|}{ Total } & & 100.0 & \\
\hline \multicolumn{5}{|c|}{ Others } \\
\hline 28 & Dynamite & 37.28 & & 30.42 \\
\hline & & & & \\
\hline & & & & \\
\hline
\end{tabular}

